\title{
Anti-inflammatory activities of ethanol leaves extract and solvent fractions of Zehneria scabra (Cucurbitaceae) in rodents
}

\author{
REDIET BELAY, EYASU MAKONNEN \\ Department of Pharmacology, School of Medicine, College of Health Sciences, Addis Ababa University. Addis Ababa, Ethiopia, \\ "email: eyasu.makonnen@aau.edu.et
}

Manuscript received: 9 August 2019. Revision accepted: 22 February 2020.

\begin{abstract}
Belay R, Makonnen E. 2020. Anti-inflammatory activities of ethanol leaves extract and solvent fractions of Zehneria scabra (Cucurbitaceae) in rodents. Biofarmasi J Nat Prod Biochem 18: 42-56. Zehneria scarba (L.f.) Sond is one of the medicinal plants used in folkloric medicine of Ethiopia for years to treat various inflammatory disorders. The present study was aimed to validate the antiinflammatory activity of crude $70 \%$ ethanol leaves extract (70EE) against a sub-acute model and further evaluate the solvent fractions ( $\mathrm{AF}, \mathrm{BF}$, and $\mathrm{CF}$ ) in an acute (carrageenan-induced paw edema), sub-acute (formaldehyde induced arthritis) and chronic (cotton pellet induced granuloma) inflammatory models. The 70EE was first prepared by maceration, and the fractions were obtained by sequential partitioning with chloroform and n-butanol from the aqueous suspension of crude 70EE. The test groups then received 100, 200, and 400 $\mathrm{mg} / \mathrm{kg}$ of the crude 70EE or the fractions (AF, BF, and CF) at the same dose levels. In contrast, positive controls received aspirin (200 $\mathrm{mg} / \mathrm{kg}$ ) or dexamethasone $(0.5 \mathrm{mg} / \mathrm{kg}$ ) and negative controls received vehicle (2\% tween 80 or distilled water, $10 \mathrm{~mL} / \mathrm{kg}$ ). All tested doses of the crude 70EE showed significant inhibition of formaldehyde-induced arthritis on the $10^{\text {th }}$ day of treatment. The $400 \mathrm{mg} / \mathrm{kg}$ dose showed the maximum anti-arthritic effect $(\% \mathrm{~A}=60.5 ; \mathrm{p}<0.001)$. In the carrageenan-induced paw edema, all three fractions showed a statistically significant effect, in fact, with different onset and magnitude. In this model, the AF was found to be the most active fraction, and the $400 \mathrm{mg} / \mathrm{kg}$ dose demonstrated the maximum effect $(\% \mathrm{~A}=76.25 ; \mathrm{p}<0.001)$ at $5 \mathrm{~h}$ post-induction, which is much better than the effect of aspirin at the dose employed. The overall order of efficacy in inhibiting the exudative component of carrageenan-induced paw edema was found to be AF> BF $>\mathrm{CF}$. The AF was also the most active fraction in inhibiting the exudative component of chronic inflammation in the cotton pellet-induced granuloma model, where the maximum effect $(\% \mathrm{~A}=43.10, \mathrm{p}<0.001)$ was exhibited by a dose of $400 \mathrm{mg} / \mathrm{kg}$. The AF was also the most active fraction in inhibiting formaldehyde-induced arthritis, in which the BF and CF relatively showed a comparable effect throughout days 4-10. On the contrary, in the cotton pellet-induced granuloma model, the $\mathrm{CF}$ was the most active fraction in inhibiting the proliferative and granulomatous component of chronic inflammation. The overall order of effectiveness was found to be CF> AF> BF. Besides, $400 \mathrm{mg} / \mathrm{kg}$ of CF demonstrated the maximum inhibition of granuloma formation $(\% \mathrm{~A}=55.52 ; \mathrm{P}<0.001)$. The phytochemical analysis revealed the differential distribution of secondary metabolites into the three fractions, which either singly or in concert appeared to be responsible for the observed effects. The data obtained from the present study collectively indicate that the extract and fractions of leaves of Z.scabra possessed a significant antiinflammatory activity, upholding the folkloric use of the plant.
\end{abstract}

Keywords: Anti-inflammatory, arthritis, granuloma, phytochemical, Zehneria scarba

\section{INTRODUCTION}

Inflammation is central to many diseases that affect both developed and emerging nations. Virtually all acute and chronic diseases are either driven or modulated by inflammation (Vodovotz et al., 2010). Despite this fact, the complex interplay between beneficial and harmful arms of the inflammatory response underlies the lack of safe and fully effective therapies for many pathologies (Vodovotz et al., 2009). On top of this, most existing drugs suffer from diverse adverse events, especially at higher doses and longer duration of therapy (Spies et al., 2011).

Non-steroidal anti-inflammatory drugs (NSAIDs), for example, are associated with the development of gastric or duodenal ulceration, nephrotoxicity, bronchospasm, exacerbation of symptoms of asthma, an increase in blood pressure, and increased incidence of myocardial infarction and stroke (Ong et al. 2007; Stanos 2013). On the other hand, corticosteroids are associated with numerous side effects, such as diabetes mellitus/glucose intolerance, hypertension, obesity, osteoporosis, immune suppression, glaucoma, and growth retardation in children (Spies et al. 2011; Rhen and Cidlowski 2005). Because of this, WHO advocates the inclusion of herbal medicines with proven safety and efficacy in healthcare programs because of the high potential they hold in combating various diseases (WHO 2002).

Z.scabra is one of these plants whose $80 \%$ methanol leaf extract has been proven anti-inflammatory and analgesic activity. Such a plant exhibiting antiinflammatory, analgesic (Akele 2012), antifungal (Arulappan et al. 2015), and antibacterial activity (Anand et al. 2012) would improve patient compliance and has economic importance. However, there is a shortage of scientific evidence to substantiate further the plant's therapeutic potential in different inflammatory models.

Hence, this study focuses on an in-vivo antiinflammatory activity of 70EE, and solvent fractions of $Z$. scabra leave using acute (carrageenan-induced paw edema), sub-acute (formaldehyde induced arthritis), and 
chronic (cotton pellet induced granuloma) models of inflammation to validate its acclaimed use by the traditional practitioners.

Moreover, it also tries to identify the most active fraction to give a clue for further investigation in search of the specific agent(s) responsible for the anti-inflammatory effect of the plant. Besides, the finding of this study might provide a clue about the possible mechanisms of antiinflammatory action of the plant. It might serve as baseline information for the scientific community to further investigate the plant by initiating advanced studies on molecular mechanisms to identify the specific agent(s) responsible for the anti-inflammatory effect of the most active fraction.

The aims of this research were (i) To assess the acute toxicity of 70EE and solvent fractions of Zehneria scabra leaves in mice, (ii) To evaluate the effect of crude 70EE of Zehneria scabra leaves on formaldehyde-induced arthritis in mice, (iii) To assess the effect of chloroform, n-butanol and aqueous fractions of Zehneria scabra leaves on carrageenan-induced paw edema in mice, (iv) To evaluate the effect of chloroform, n-butanol and aqueous fractions of Zehneria scabra leaves on formaldehyde-induced arthritis in mice, (v) To assess the impact of chloroform, nbutanol and aqueous fractions of Zehneria scabra leaves using cotton pellet induced granuloma in rats, (vi) To determine the phytochemical constituents of the 70EE and solvent fractions of Zehneria scabra leaves.

\section{MATERIALS AND METHODS}

\section{Drugs and chemicals}

Aspirin active (EPHARM, Ethiopia), Dexamethasone (Medico Labs, Lot E6A00, Syria), Carrageenan (Sigma Aldrich, Germany), thiopental sodium (NEON Labs, India); ethanol (Lot 30320601EX) and formaldehyde (Research-Lab Fine Chem Industries- India); n-butanol (Lot 10061), chloroform (Lot 10077), and glacial acetic acid (Lot MR0478) (BDH chemical LTD Poole, England); acetic anhydride (Lot A13/45/67/A) and Mayer's reagent (May \& Baker LTD Dagenham, England); Dragendroff's reagent and sulfuric acid (Lot 30326) (Fisher Scientific, UK); ammonia, hydrochloric acid, and ferric chloride (Lot 10111) (BDH Laboratory Supplies Poole, England); normal saline (Addis Pharmaceutical Factory, Ethiopia), distilled water (Biochemistry Laboratory of AAU, Ethiopia), tween 80 (UNI-CHEM Chemical Reagents, India), were used in the study and all were of analytical grade.

\section{Materials and instruments}

Rotary evaporator (Heidolph, Germany), lyophilizer (OPERON, OPR-FDU-5012, Korea), digital plethysmometer (Ugo Basile-Cat no 7140, Italy), electronic balance (KERN-ALJ 220-4, Germany), mini orbital shaker (SSM1-STUART), Tissue Drying Oven (Medite - Medizin Technik, Germany), separatory funnel, flasks, Cotton pellets, syringes with needles, feeding tube, blunt forceps, scissors, suturing set.

\section{Plant material collection and authentication}

The fresh leaves of Zehneria scabra were collected in the Lideta sub-city, Addis Ababa, Ethiopia, in December 2014. Identification and authentication of the plant specimen were made at the National Herbarium, College of Natural and Computational Sciences, Addis Ababa University, and a voucher specimen was deposited with voucher number RB 001/2014 for future reference. The leaves were washed gently by rinsing with running water to remove dust particles, air-dried under the shade, and then reduced into a coarse powder with mortar and pestle.

\section{Experimental animals}

Healthy male (for the anti-inflammatory test) and female (for acute toxicity test) Swiss albino mice weighing 20-30 g and male albino Wistar rats weighing 180-220 g were obtained from the animal house of the Ethiopian Public Health Institute and Department of Pharmacology, School of medicine, Addis Ababa University were used. They were kept in plastic cages at room temperature on a $12 \mathrm{~h}$ light-dark cycle with free access to pellet food and water ad libitum. The animals were acclimatized to laboratory conditions for one week before the commencement of the experiments. All experiments were carried out during the light period of the day (9:00 a.m. 5:00 p.m.) and followed the guideline for the care and use of laboratory animals (Institute for Laboratory Animal Research 1996; OECD 2008). The study was conducted after approval by Addis Ababa University, College of Health Sciences Institution Review Board (IRB).

\section{Preparation of crude extracts and solvent fractions of $Z$. scabra leaves}

The air-dried and powdered leaves of Z. scabra were first defatted by macerating with petroleum ether for 24 hours at room temperature and occasionally shaking, followed by filtration. The solvent (petroleum ether) was removed from the residue by exposing it to open air. Then the defatted coarse powder was divided into two halves of $665 \mathrm{gm}$ each for the extraction process. The first half (665gm of the leave) was macerated in a flask containing $70 \%$ ethanol $(1: 5 \mathrm{w} / \mathrm{v})$ for $72 \mathrm{hrs}$, and the other half was macerated with distilled water with the same ration and for the same period. The maceration was undertaken with occasional shaking using a mini orbital shaker tuned to 120 rpm for $72 \mathrm{hrs}$ at room temperature. Then, the extract was filtered first using a muslin cloth and then using Whatman filter paper (No 1), and the marc was re-macerated for a second and third time by adding another fresh solvent.

The three batches of the 70EE filtrates were combined and concentrated in a rotary evaporator with a temperature of $40{ }^{\circ} \mathrm{C}$. The concentrate was then placed in a deep freezer operating at negative $20^{\circ} \mathrm{C}$ until it formed a block of ice, and then the remaining solvent (water) was removed using a lyophilizer. After water removal, a black powder residue weighing $88 \mathrm{gm}$ was obtained, giving rise to a percentage yield of $13.23 \%$. The filtrates from the three batches of the aqueous extract were also combined, placed in a deep freezer at $-20^{\circ} \mathrm{C}$ to form ice, and lyophilized. The water extract yields $39.34 \mathrm{gm}$ of black powder $(5.92 \% \mathrm{w} / \mathrm{w})$. The 
powders were kept in tightly stoppered bottles and stored in a deep freezer at $-20^{\circ} \mathrm{C}$ until the commencement of the pilot study.

The hydroalcoholic extract (70EE) (which had a better activity) was selected for further fractionation based on the pilot experiment performed. A total of eighty grams of the powdered residue of the 70EE was divided into four equal parts (20gm each) and then employed for the fractionation. At a time, the 70EE (20 g) aliquot was suspended in distilled water $(100 \mathrm{~mL})$ and then sequentially partitioned with chloroform and $n$-butanol at room temperature using a separatory funnel. Partitioned layers of each solvent were pooled together and concentrated on a rotary evaporator at $40^{\circ} \mathrm{C}$, followed by an oven at room temperature for $48 \mathrm{~h}$, yielding $13.4 \mathrm{gm}$ of black gummy residue from the chloroform fraction $(16.75 \% \mathrm{w} / \mathrm{w})$, and $16.73 \mathrm{gm}$ of light brown slightly hygroscopic powder from the $n$-butanol fraction $(20.91 \% \mathrm{w} / \mathrm{w})$. The aqueous residue was lyophilized to give $38.85 \mathrm{gm}$ of black dried powder $(48.56 \% \mathrm{w} / \mathrm{w})$ fraction. The fractions were kept in tightly stoppered bottles and stored in a deep freezer at $-20^{\circ} \mathrm{C}$ until the commencement of the actual experiment. Finally, the portions were reconstituted in distilled water $/ 2 \%$ tween 80 at appropriate concentrations for the various trials.

\section{Acute oral toxicity test}

An acute oral toxicity test for 70EE and solvent fractions of the leaves of Z. scabra was performed according to the Organization for Economic Cooperation and Development (OECD) guideline 425; "Limit Test at $2000 \mathrm{mg} / \mathrm{kg}^{\prime}$ (2008). Five female albino mice of 6-8 weeks were used for each test. All mice fasted for four $\mathrm{h}$ before and two $\mathrm{h}$ after administering the extract/fractions. First, a sighting study was performed to determine the starting dose, in which a single female mouse was given 2000 $\mathrm{mg} / \mathrm{kg}$ of the extract/fractions as a single dose by oral gavage. Since no death was observed within $24 \mathrm{~h}$, four additional mice were used for each extract and fraction and administered the same dose of extract/fractions. The animals were observed continuously for $4 \mathrm{~h}$ with $30 \mathrm{~min}$ intervals and then for 14 consecutive days with a range of $24 \mathrm{~h}$ for the general signs and symptoms of toxicities such as changes in skin and fur, eyes and mucous membranes, somatomotor activity, and behavioral pattern, salivation and diarrhea, weight loss, tremor and convulsions, lethargy and paralysis, food and water intake and mortality.

\section{Pilot study}

The pilot study was done using the Carrageenaninduced paw edema acute model of inflammation on $70 \%$ ethanol leave extract (70EE), aqueous leave extracts (AE), and petroleum ether extract (PE) of Z. scabra. All three extracts were administered at doses of 100, 200, and $400 \mathrm{mg} / \mathrm{kg}$, and three animals per group were used at all the dose levels. The result indicated that both the $\mathrm{AE}$ and 70EE have anti-inflammatory activity; even though the 70EE had shown a better anti-inflammatory effect $(\% \mathrm{~A})$ at all employed doses (maximum $\% \mathrm{~A}$ at the $5^{\text {th }} \mathrm{h}=37 \%$ for $100 \mathrm{mg} / \mathrm{kg}, 45 \%$ for $200 \mathrm{mg} / \mathrm{kg}$, and $52 \%$ for $400 \mathrm{mg} / \mathrm{kg}$ ) than the $\mathrm{AE}$ (maximum $\% \mathrm{~A}$ at the $5^{\text {th }} \mathrm{h}=19 \%$ for
$100 \mathrm{mg} / \mathrm{kg}, 28 \%$ for $200 \mathrm{mg} / \mathrm{kg}$, and $41 \%$ for $400 \mathrm{mg} / \mathrm{kg}$ ). On the other hand, the PE extract failed to demonstrate antiinflammatory activity at all employed doses. Hence, the $70 \mathrm{EE}$ opted for further study and fractionation.

\section{Animal grouping and dosing}

The animals were randomly assigned into twelve groups of six to perform the anti-inflammatory activity test in three models. The first two groups served as negative controls, and the vehicles for the fractions (distilled water and $2 \%$ tween 80 at a dose of $10 \mathrm{~mL} / \mathrm{kg}$ ) were administered. The third group served as a positive control. The standard drugs aspirin $(200 \mathrm{mg} / \mathrm{kg}$ p.o. in the acute and sub-acute models) or dexamethasone $(0.5 \mathrm{mg} / \mathrm{kg}$ p.o. in the chronic model) was administered to this group. The first three test groups (4-6) received three doses (100, 200, and $400 \mathrm{mg} / \mathrm{kg}$ ) of the aqueous fraction. The next three test groups (7-9) received n-butanol fraction at doses of 100 , 200 , and $400 \mathrm{mg} / \mathrm{kg}$, while the final three test groups (1012) received the chloroform fraction at the same three dose levels. The same dose levels were also applied during an anti-inflammatory test of the crude extract using formaldehyde-induced arthritis in mice, during which a total of five groups, i.e., two control groups (positive and negative) and three test groups of 70EE (100, 200, and $400 \mathrm{mg} / \mathrm{kg}$ ) were used. The dose levels $(100,200$, and $400 \mathrm{mg} / \mathrm{kg}$ ) were selected based on the acute oral toxicity test results and pilot study.

\section{Determination of anti-inflammatory activity Carrageenan-induced paw edema}

The method described by Mequanint et al. (2011) was followed in this model to study the effect of solvent fractions of Z. scabra leaves on acute inflammation. Mice fasted for $12 \mathrm{~h}$ with free access to water until the experiment started and grouped and treated by oral gavage as described under section 3.8. Aspirin $200 \mathrm{mg} / \mathrm{kg}$ p.o. was administered as a standard drug. The right hind paw was marked with ink at the level of lateral malleolus so that it could always be immersed to the same extent in the measurement chamber of the plethysmometer.

An hour later, edema was induced by injecting $0.05 \mathrm{~mL}$ of $1 \% \mathrm{w} / \mathrm{v}$ carrageenan in normal saline into the right hind paw of each mouse. The increased volume of the right hind paws was taken to signify paw edema. Paw volume was determined by volume displacement technique using the Ugo-Basile plethysmometer just before carrageenan injection (initial amount $\left(\mathrm{v}_{0}\right)$ ), and 1, 2, 3, 4, and $5 \mathrm{~h}$ after carrageenan injection (final volumes $\left(\mathrm{v}_{\mathrm{f}}\right)$ ). The degree of swelling, i.e., edema, was evaluated by the delta volume $\left(\mathrm{v}_{\mathrm{f}}-\mathrm{v}_{0}\right)$ (Sanusi et al., 2013).

\section{Oedema $(\mathrm{I})=\mathrm{V}_{\mathrm{f}}-\mathrm{V}_{0}$}

Where: $V_{0}$ is the paw volume before the carrageenan injection, and $\mathrm{V}_{\mathrm{f}}$ is the paw volume after the carrageenan injection at a given time.

Also, the anti-inflammatory effect of the fractions expressed in percentage (\%A) was calculated according to the formula given by Sanusi et al. (2013): 
$\%$ inhibition $(\% \mathrm{~A})=\left(1-\frac{\mathrm{It}}{\mathrm{Ic}}\right) \times 100$

Where: It and Ic are the mean inflammation (Oedema) values reached at a given time in treatment and control groups, respectively.

\section{Formaldehyde induced arthritis}

The method described by Mehta et al. (2012) and Cui et al. (2014) was used as a subacute inflammation model. Mice (20-30 g) fasted for $12 \mathrm{~h}$ with free access to water until the commencement of the experiment. The right hind paw was marked with ink at the level of lateral malleolus so that it could always be immersed to the same extent in the measurement chamber of the plethysmometer. The control, standard, and test groups of mice received distilled water (2\% tween 80 in case of chloroform fraction), Aspirin (200mg/kg p.o.), and extract/fractions, respectively, as described in section 3.8. On the first day, the basal paw volume $\left(\mathrm{V}_{0}\right)$ of the right hind paw of each mouse was measured using a plethysmometer. On day one and day 3 , mice were injected into the sub-plantar region of the right hind paw with $0.05 \mathrm{~mL}$ of $2 \% \mathrm{v} / \mathrm{v}$ formaldehyde in normal saline. Dosing with vehicles, standard drug (Aspirin), and extract/fractions was started on the same day an hour before induction of arthritis and continued for ten consecutive days by oral gavage. The mice paw volume was recorded daily using a plethysmometer after one $h$ of drug administration, but on day one, the measurement was taken three $h$ after formaldehyde injection. Finally, the percentage of inhibition of edema was calculated, as described in section 3.9.1.

\section{Cotton pellet induced granuloma method}

The method previously described by Afsar et al. (2013) was used to assess chronic inflammation's transudative and proliferative (granulomatous) components. Male albino Wistar rats (180-220 g) fasted for $12 \mathrm{~h}$ with free access to water until the commencement of the experiment. The control, standard, and test groups of rats received distilled water ( $2 \%$ tween 80 in case of chloroform fraction), dexamethasone $(0.5 \mathrm{mg} / \mathrm{kg} \quad$ p.o. $)$, and fractions, respectively, as described in section 3.8 .

Cotton pellets weighing ten $\pm 1 \mathrm{mg}$ were sterilized in an autoclave for $30 \mathrm{~min}$ at $120 \mathrm{C}^{0}$ under $15 \mathrm{Ib}$ pressure. Twenty minutes after treatment with the standard drug and fractions, the rats were anesthetized with thiopental sodium (25 mg/kg, i.p.). The subcutaneous tunnel was made aseptically using blunted forceps on both sides of each rat's previously shaved groin region. Two sterilized cotton pellets weighing $10 \pm 1 \mathrm{mg}$ each were implanted bilaterally in the subcutaneous tunnel and sutured with chromic catgut (0/4metric-1/2 Circle). Treatment with the standard drug (dexamethasone) and fractions continued for seven consecutive days (p.o., once a day). On the 8th day, the rats were sacrificed with ether anesthesia; then, the pellets surrounded by granuloma tissue were dissected carefully and freed from extraneous tissue. The wet weight of the cotton was taken immediately after removal and then dried up to constant weight at $60^{\circ} \mathrm{C}$ for $24 \mathrm{hrs}$, and the net dry weight, that is, after subtracting the weight of the cotton pellets.

The exudate amount (mg), granulation tissue formation (mg), and percent inhibition of exudate and granuloma tissue formation were calculated according to the formula given by Aziz et al. (2014):

$$
\text { Exudate inhibition }(\%)=\left(1-\frac{\text { Exudate in treated group }}{\text { Exudate in controls }}\right) \mathrm{X} 100
$$

Granuloma inhibition $(\%)=\left(1-\frac{\text { Granuloma in treated group }}{\text { Granuloma in controls }}\right) \times 100$

Where:

The measure of exudate formation = immediate wet weight of pellet - Constant dry weight of the pellet

The measure of granuloma tissue formation $=$ Constant dry weight - Initial weight of the cotton pellet.

\section{Preliminary phytochemical screening}

The initial phytochemical screening of secondary metabolites of 70EE, and chloroform, n-butanol, and aqueous fractions of leaves of Z.scabra were carried out using standard tests (Debella 2002; Sasidharan et al. 2011).

\section{Test for saponins}

To $0.25 \mathrm{~g}$ of 70EE and each fraction (AF, BF, and $\mathrm{CF}$ ), $5 \mathrm{~mL}$ of distilled water was added to a test tube. Then, the solution was shaken vigorously and observed for a stable, persistent froth. The formation of a stable froth that persisted for about half an hour indicated the presence of saponins.

\section{Test for terpenoids}

To $0.25 \mathrm{~g}$ of $70 \mathrm{EE}$ and each fraction, $2 \mathrm{~mL}$ of chloroform was added. Then, $3 \mathrm{~mL}$ concentrated sulfuric acid was carefully added to form a layer. A reddish-brown coloration of the interface indicated the presence of terpenoids.

\section{Test for tannins}

About $0.25 \mathrm{~g}$ of $70 \mathrm{EE}$, each fraction was boiled in 10 $\mathrm{mL}$ of water in a test tube and filtered with filter paper (Whatman No. 1). A few drops of $0.1 \%$ ferric chloride were added to the filtrate. A brownish-green or a blueblack precipitate indicated the presence of tannins.

\section{Test for flavonoids}

About $10 \mathrm{~mL}$ of ethyl acetate was added to $0.2 \mathrm{~g}$ of $70 \mathrm{EE}$, and each fraction and heated in a water bath for 3 min. The mixture was cooled and filtered. Then, about 4 $\mathrm{mL}$ of the filtrate was shaken with $1 \mathrm{~mL}$ of dilute ammonia solution. The layers were allowed to separate, and the yellow color in the ammonia layer indicated the presence of flavonoids.

\section{Test for cardiac glycosides}

To $0.25 \mathrm{~g}$ of $70 \mathrm{EE}$ and each fraction diluted with $5 \mathrm{~mL}$ of water, $2 \mathrm{~mL}$ of glacial acetic acid containing one drop of 
ferric chloride solution was added. This was underlaid with $1 \mathrm{~mL}$ of concentrated sulfuric acid. A brown ring at the interface indicated the presence of a deoxysugar characteristic of cardenolides.

\section{Test for steroids}

Two $\mathrm{mL}$ of acetic anhydride was added to $0.25 \mathrm{~g}$ of $70 \mathrm{EE}$ and each fraction with $2 \mathrm{~mL}$ sulfuric acid. The color change from violet to blue or green in some samples indicated the presence of steroids.

\section{Test for alkaloids}

$0.5 \mathrm{~g}$ of 70EE, and each fraction was diluted to $10 \mathrm{~mL}$ with acid alcohol, boiled, and filtered. To $5 \mathrm{~mL}$ of the filtrate, $2 \mathrm{~mL}$ of dilute ammonia and $5 \mathrm{~mL}$ of chloroform were added and shaken gently to extract the alkaloidal base. The chloroform layer was extracted with $10 \mathrm{~mL}$ of acetic acid. This was divided into two portions. Mayer's reagent was added to one part, and Dragendorff's reagent to the other. The formation of cream (with Mayer's reagent) or reddish-brown precipitate (with Dragendorff's reagent) was regarded as positive for the presence of alkaloids.

\section{Statistical analysis}

The data were analyzed using SPSS version 16.0 for Windows. The experimental results are expressed as mean \pm standard error of the mean (SEM), and statistical significance was carried out by employing a one-way analysis of variance (ANOVA) followed by the Tukey post hoc test for multiple comparisons to compare results among groups, where $\mathrm{p}$ values $<0.05$ were considered statistically significant. The analyzed data were then presented using tables. Linear regression was also used where appropriate.

\section{RESULTS AND DISCUSSION}

\section{Acute oral toxicity test}

The acute oral toxicity test of 70EE and fractions (AF, $\mathrm{BF}$, and $\mathrm{CF}$ ) of leaves of Z. scabra showed that neither the 70EE nor the solvent fractions caused gross behavioral changes, toxic effects, or mortality within $24 \mathrm{~h}$ and in the next 14 days. According to the "Limit Test at $2000 \mathrm{mg} / \mathrm{kg}$ " of OECD guideline 425 (2008), it can be concluded that the oral $\mathrm{LD}_{50}$ of both the crude $70 \mathrm{EE}$ and solvent fractions are more significant than $2000 \mathrm{mg} / \mathrm{kg}$ in mice.

\section{Carrageenan induced paw edema}

Subplantar injection of $0.05 \mathrm{~mL}$ of $1 \%$ carrageenan to the mice's hind paw produced a progressive increment of paw thickness that reached its maximum value after $3 \mathrm{~h}$ of induction in both distilled water and $2 \%$ tween vehicle controls (Table 1). All tested doses of the aqueous fraction $(100,200$, and $400 \mathrm{mg} / \mathrm{kg}$ of AF) showed significant inhibition of paw edema that started from $1 \mathrm{~h}(\mathrm{p}<0.01)$, and the effect lasted till $5 \mathrm{~h}$ post-induction $(\mathrm{p}<0.001$ from $2^{\text {nd }}-5^{\text {th }} \mathrm{h}$ ) as compared to the distilled water vehicle control.

Maximum anti-inflammatory effect (\%A) by the 100 , 200 and $400 \mathrm{mg} / \mathrm{kg}$ of $\mathrm{AF}$ was observed at $5 \mathrm{~h}$ post- induction, with respective values of $50.97 \%, 72.02 \%$, and $76.25 \%$, and the effect at this hour was found to increase in dose-dependent manner $\left(\mathrm{R}^{2}=0.721\right)$. Intergroup comparison among doses of the AF also showed a statistically significant different effect in both 200 versus $100 \mathrm{mg} / \mathrm{kg}(\mathrm{p}<0.05$ at $4 \mathrm{~h}$ and $5 \mathrm{~h})$, and 400 versus $100 \mathrm{mg} / \mathrm{kg}(\mathrm{p}<0.05$ at $4 \mathrm{~h}$, and $\mathrm{p}<0.01$ at $5 \mathrm{~h})$.

Unlike the AF, only the higher doses of butanol fraction $(200 \mathrm{mg} / \mathrm{kg}$ and $400 \mathrm{mg} / \mathrm{kg}$ of $\mathrm{BF})$ showed statistically significant inhibition of paw edema at $1 \mathrm{~h}$ post-induction as compared to distilled water vehicle control, with $\mathrm{p}<0.05$ and $\mathrm{p}<0.01$, respectively. The effect in both dose levels then persisted from the $2^{\text {nd }}-5^{\text {th }}$ h post-induction with $\mathrm{p}<$ 0.001 , except at the $3^{\text {rd }} \mathrm{h}$ where $\mathrm{p}<0.01$ for $200 \mathrm{mg} / \mathrm{kg}$ compared to the negative control. However, the $100 \mathrm{mg} / \mathrm{kg}$ of $\mathrm{BF}$ failed to demonstrate statistically significant inhibition of paw edema compared to the negative control except at two h post-induction, where $\mathrm{p}<0.05$.

Like the AF, maximum percent inhibition by the 100 , 200 , and $400 \mathrm{mg} / \mathrm{kg}$ of BF was observed at five $\mathrm{h}$ postinduction, with respective values of $19.93 \%, 43.29 \%$, and $51.33 \%$, and the anti-inflammatory effect was found to increase in a dose-dependent manner $\left(\mathrm{R}^{2}=0.799\right)$. Intergroup comparison among doses of the BF also showed a statistically significant different effect in both 200 versus $100 \mathrm{mg} / \mathrm{kg}(5 \mathrm{~h}, \mathrm{p}<0.05)$ and 400 versus $100 \mathrm{mg} / \mathrm{kg}(2 \mathrm{~h}, \mathrm{p}$ $<0.05$ and $3-5 \mathrm{~h}, \mathrm{p}<0.01)$.

The higher doses of chloroform fraction $(\mathrm{CF})$, on the other hand, significantly inhibited paw edema as compared to the $2 \%$ tween vehicle control only late at the $4^{\text {th }} \mathrm{h}$ (p < 0.05 for $200 \mathrm{mg} / \mathrm{kg} ; \mathrm{p}<0.01$ for $400 \mathrm{mg} / \mathrm{kg})$, and $5^{\text {th }} \mathrm{h}(\mathrm{p}<$ 0.01 for $200 \mathrm{mg} / \mathrm{kg} ; \mathrm{p}<0.001$ for $400 \mathrm{mg} / \mathrm{kg}$ ) post induction. The $100 \mathrm{mg} / \mathrm{kg}$ of $\mathrm{CF}$, however, did not show significant inhibition of paw edema as compare to the negative control throughout the observation period. Interestingly, no significant difference was noted among the doses of $\mathrm{CF}$, except at $5 \mathrm{~h}$ post induction where $400 \mathrm{mg} / \mathrm{kg}$ showed a statistically significant inhibition $(\mathrm{p}<$ $0.05 ; \% \mathrm{~A}=39.31)$ as compared to $100 \mathrm{mg} / \mathrm{kg}(\% \mathrm{~A}=$ 12.63), and the effect at this hour was found to increase dose dependently $\left(\mathrm{R}^{2}=0.931\right)$.

Significant inhibition of paw edema occurred with $200 \mathrm{mg} / \mathrm{kg}$ of aspirin from the $1^{\text {st }} \mathrm{h}(\mathrm{p}<0.01)$ till the $5^{\text {th }} \mathrm{h}$ after carrageenan injection $\left(\mathrm{p}<0.001\right.$ from $2^{\text {nd }}-5^{\text {th }} \mathrm{h}$ ) as compared to the negative control. Moreover, no difference in onset and duration of action was observed among all tested doses of the AF, 200 and $400 \mathrm{mg} / \mathrm{kg}$ of the BF, and $200 \mathrm{mg} / \mathrm{kg}$ of aspirin, as all showed significant inhibition of paw edema from the $1^{\text {st }} \mathrm{h}$ till the $5^{\text {th }} \mathrm{h}$ post-induction. Nevertheless, 200 and $400 \mathrm{mg} / \mathrm{kg}$ of the AF showed a higher anti-inflammatory effect $(\% \mathrm{~A})$ than that of $200 \mathrm{mg} / \mathrm{kg}$ of aspirin throughout the observation period, whereas $100 \mathrm{mg} / \mathrm{kg}$ of $\mathrm{AF}$ had shown a comparable antiinflammatory impact with $200 \mathrm{mg} / \mathrm{kg}$ of aspirin (Table 1).

Therefore, it can be concluded that the AF was the most active fraction in terms of anti-inflammatory effects on carrageenan-induced mice paw edema. This is evidenced by the higher percent inhibition $(\% \mathrm{~A})$ values of all tested doses of $\mathrm{AF}$ compared to the equivalent doses of the $\mathrm{BF}$ and $\mathrm{CF}$. 
The reference drug, $200 \mathrm{mg} / \mathrm{kg}$ of aspirin, showed significant inhibition of paw edema beginning from day 2 of treatment. The effect lasted till day 10 with $\mathrm{p}<0.001$, but on day $4 \mathrm{p}<0.01$ compared to the negative control. Maximum percentage inhibition $(57.44 \%$ ) by $200 \mathrm{mg} / \mathrm{kg}$ of aspirin was noted on day 3 of treatment. Moreover, no significant difference in onset of action was observed among aspirin; all three doses of AF, 200 and $400 \mathrm{mg} / \mathrm{kg}$ of $\mathrm{BF}$, and the highest dose $(400 \mathrm{mg} / \mathrm{kg})$ of $\mathrm{CF}$ all showed a statistically significant inhibition starting from the $2^{\text {nd }}$ day of treatment. Furthermore, $100 \mathrm{mg} / \mathrm{kg}$ of $\mathrm{AF}$ and the BF at 200 and $400 \mathrm{mg} / \mathrm{kg}$ showed a comparable anti-inflammatory effect $(\% \mathrm{~A})$ with $200 \mathrm{mg} / \mathrm{kg}$ of aspirin. The 200 and $400 \mathrm{mg} / \mathrm{kg}$ of $\mathrm{AF}$, on the other hand, exhibited a significantly higher anti-inflammatory effect than $200 \mathrm{mg} / \mathrm{kg}$ aspirin throughout days $3-10$, as shown in Table 3.

Even though all three fractions, of course, showed significant inhibition of paw edema at different doses compared to their respective negative controls, the AF was found to be the most active fraction in terms of the antiinflammatory effect on formaldehyde-induced arthritis in mice. This is evidenced by the higher percent inhibition value of the $\mathrm{AF}$ throughout the observation period compared to the equivalent doses of $\mathrm{BF}$ and $\mathrm{CF}$.

\section{Cotton pellet induced granuloma}

Subcutaneous implantation of two pellets of cotton, each weighing ten $\pm 1 \mathrm{mg}$ in the groin region of rats, induced granulomatous inflammation with a maximum granuloma weight and exudates observed in distilled water and $2 \%$ tween 80 received negative controls as shown in Table 4. The aqueous fraction (AF) at all tested doses significantly inhibited the formation of inflammatory exudates $(\mathrm{p}<0.001)$ and granuloma mass $(\mathrm{P}<0.01$ for $100 \mathrm{mg} / \mathrm{kg} ; \mathrm{p}<0.001$ for 200 and $400 \mathrm{mg} / \mathrm{kg}$ ) as compared to the negative control.

Intergroup comparisons among doses of the $\mathrm{AF}$ revealed a statistically significant different effect in 400 versus $200 \mathrm{mg} / \mathrm{kg}$ ( $\mathrm{p}<0.05$ in exudates inhibition; $\mathrm{p}<$ 0.001 in granuloma inhibition), 400 versus $100 \mathrm{mg} / \mathrm{kg}$ ( $\mathrm{P}<$ 0.001 in both exudates and granuloma inhibition), and 200 versus $100 \mathrm{mg} / \mathrm{kg}$ ( $\mathrm{p}<0.001$ in exudates inhibition). Furthermore, the anti-inflammatory effect of the AF was found to increase in dose dependent manner $\left(R^{2}=0.829\right.$ for exudates inhibition; $\mathrm{R}^{2}=1$ for granuloma inhibition).

All tested doses of the chloroform fraction $(\mathrm{CF})$ significantly $(p<0.001)$ inhibited the formation of both inflammatory exudates and granuloma mass as compared to the $2 \%$ tween negative controls. Comparison among doses of the CF revealed a statistically significant different effect in 200 versus $100 \mathrm{mg} / \mathrm{kg}$ ( $\mathrm{p}<0.01$ in exudates inhibition), 400 versus $200 \mathrm{mg} / \mathrm{kg}$ ( $\mathrm{P}<0.01$ in granuloma inhibition), and 400 versus $100 \mathrm{mg} / \mathrm{kg}$ ( $\mathrm{p}<0.001$ in both exudates and granuloma inhibition). Besides, the antiinflammatory effect of the CF was ascertained to increase in a dose-dependent manner $\left(\mathrm{R}^{2}=0.928\right.$ for exudates inhibition; $\mathrm{R}^{2}=0.998$ for granuloma inhibition). Furthermore, the maximum anti-proliferative effect (peak percentage inhibition of granuloma formation, 55.52\%) was shown at $400 \mathrm{mg} / \mathrm{kg}$ of $\mathrm{CF}$ compared to all other $\mathrm{CF}$, $\mathrm{BF}$, and AF doses.

The butanol fraction (BF), on the other hand, showed significant inhibition of both inflammatory exudates $(\mathrm{p}<$ $0.001)$ and granuloma mass $(\mathrm{p}<0.01)$ only at the highest tested dose $(400 \mathrm{mg} / \mathrm{kg})$ as compared to the distilled water vehicle control. The $200 \mathrm{mg} / \mathrm{kg}$ of BF showed a significant $(\mathrm{p}<0.05)$ inhibition of exudate formation, but no considerable protection against granuloma formation was noted compared to the negative control.

The $100 \mathrm{mg} / \mathrm{kg}$ of $\mathrm{BF}$, on the other hand, failed to demonstrate significant inhibition of both exudates and granuloma formation as compared to the negative control. Intergroup comparisons among doses of the BF revealed a statistically significant different protection against exudates formation in 400 versus $200 \mathrm{mg} / \mathrm{kg}(\mathrm{p}<0.05)$ and 400 versus $100 \mathrm{mg} / \mathrm{kg}$ ( $\mathrm{p}<0.01)$. Still, no significant difference was observed among all three doses of $\mathrm{BF}$ regarding inhibition of granuloma mass formation.

The reference drug, $0.5 \mathrm{mg} / \mathrm{kg}$ of dexamethasone, significantly $(\mathrm{p}<0.001)$ inhibited the formation of both exudates $(\% \mathrm{~A}=45.07)$ and granuloma mass $(\% \mathrm{~A}=65.99)$ as compared to the negative control. The highest tested dose $(400 \mathrm{mg} / \mathrm{kg})$ of both the $\mathrm{AF}$ and $\mathrm{CF}$ showed a comparable inhibition of exudate formation with the reference drug. But a significant $(\mathrm{P}<0.01$ and $\mathrm{P}<0.001)$ difference was noted when all doses of the three fractions were compared with dexamethasone in terms of granuloma inhibition (Table 4).

As the results of this model revealed, the AF and $\mathrm{CF}$ were comparably effective at all tested doses in inhibiting cotton pellet induced exudates formation, whereas the $\mathrm{CF}$ was the most active fraction in inhibiting the formation of granuloma mass, as evidenced by the higher percentage of granuloma inhibition as compared to the respective doses of the $\mathrm{AF}$ and $\mathrm{BF}$.

\section{Phytochemical screening}

Preliminary phytochemical screening for secondary metabolites was carried out on the crude 70EE, and solvent fractions of $Z$. scabra. The result revealed a differential distribution of secondary metabolites in the solvent fractions, as shown in Table 5.

\section{Discussion}

Zehneria scabra has been used in the folk medicine of Ethiopia for the management of different inflammatory pathologies. Its use in various inflammatory conditions is recorded in ethnobotanical studies of Ethiopia with a high fidelity rate; e.g., $\mathrm{FL}=100 \%$ for febrile conditions by the ethnic groups of Gondar Zuria district (Birhanu 2013); 86\% for 'mich' by people in Zegie Peninsula (Teklehaymanot and Giday 2007); 95\% for febrile conditions by people of Ankober District, North Shewa Zone (Lulekal et al. 2013) and people of Bahirdar Zuria district (Ragunathan and Abay 2009). 
Table 1. Effects of the solvent fractions of Zehneria scabra on carrageenan-induced mouse paw edema

\begin{tabular}{|c|c|c|c|c|c|}
\hline \multirow{2}{*}{ Treatment group } & \multicolumn{5}{|c|}{ Mean increase in paw Volume \pm S.E.M and $[\%$ Inhibition $(\% \mathrm{~A})]$} \\
\hline & 1hr & $2 \mathrm{hr}$ & $3 \mathrm{hr}$ & $4 \mathrm{hr}$ & 5hr \\
\hline Distilled $\mathrm{H}_{2} \mathrm{O}$ & $0.490 \pm 0.037$ & $0.560 \pm 0.020$ & $0.598 \pm 0.028$ & $0.5167 \pm 0.030$ & $0.4350 \pm 0.024$ \\
\hline $2 \%$ Tween 80 & $0.537 \pm 0.025$ & $0.563 \pm 0.027$ & $0.610 \pm 0.025$ & $0.543 \pm 0.023$ & $0.475 \pm 0.026$ \\
\hline ASA200mg/kg & $0.343 \pm 0.025^{\mathrm{a} 2}[29.94]$ & $0.355 \pm 0.026^{\mathrm{a} 3}[36.61]$ & $0.388 \pm 0.033^{\mathrm{a} 3}[35.10]$ & $0.282 \pm 0.023^{\mathrm{a} 3}[45.48]$ & $0.180 \pm 0.023^{\mathrm{a} 3}[58.62]$ \\
\hline $\mathrm{AF} 100 \mathrm{mg} / \mathrm{kg}$ & $0.345 \pm 0.023^{\mathrm{a} 2}[29.59]$ & $0.338 \pm 0.022^{\mathrm{a} 3}[39.59]$ & $0.378 \pm 0.022^{\mathrm{a} 3}[36.77]$ & $0.303 \pm 0.024^{\text {azdiel }}[41.3]$ & $0.213 \pm 0.020^{\mathrm{a} 3 \mathrm{~d} 1 \mathrm{e} 2}[50.97]$ \\
\hline $\mathrm{AF} 200 \mathrm{mg} / \mathrm{kg}$ & $0.318 \pm 0.021^{\mathrm{a} 2}[35.04]$ & $0.277 \pm 0.027^{\mathrm{a} 3}[50.59]$ & $0.288 \pm 0.028^{\mathrm{a} 3}[51.81]$ & $0.185 \pm 0.024^{\mathrm{a} 3}[64.2]$ & $0.122 \pm 0.012^{\mathrm{a} 3}[72.02]$ \\
\hline $\mathrm{AF} 400 \mathrm{mg} / \mathrm{kg}$ & $0.317 \pm 0.024^{\mathrm{a} 2}[35.37]$ & $0.272 \pm 0.015^{\mathrm{a} 3}[51.48]$ & $0.267 \pm 0.034^{\mathrm{a} 3 \mathrm{~b} 1}[55.42]$ & $0.176 \pm 0.026^{\mathrm{a} b \mathrm{~b} 1}[65.8]$ & $0.103 \pm 0.014^{\mathrm{a} 3}[76.25]$ \\
\hline $\mathrm{BF} 100 \mathrm{mg} / \mathrm{kg}$ & $0.428 \pm 0.023[12.59]$ & $0.465 \pm 0.018^{\mathrm{alblel}}[16.96]$ & $0.493 \pm 0.022^{\mathrm{ble} 2}[17.55]$ & $0.433 \pm 0.023^{\mathrm{b} 2 \mathrm{e} 2}[16.14]$ & $0.348 \pm 0.026^{\mathrm{b} 3 \mathrm{~d} 1 \mathrm{e} 2}[19.93]$ \\
\hline $\mathrm{BF} 200 \mathrm{mg} / \mathrm{kg}$ & $0.377 \pm 0.022^{\mathrm{a}^{1}}[23.12]$ & $0.403 \pm 0.030^{\mathrm{a} 3}[27.98]$ & $0.425 \pm 0.028^{\mathrm{a} 2}[28.97]$ & $0.333 \pm 0.035^{\mathrm{a} 3}[35.49]$ & $0.247 \pm 0.030^{\mathrm{a} 3}[43.29]$ \\
\hline $\mathrm{BF} 400 \mathrm{mg} / \mathrm{kg}$ & $0.350 \pm 0.018^{\mathrm{a} 2}[28.57]$ & $0.357 \pm 0.015^{\mathrm{a} 3}[36.30]$ & $0.363 \pm 0.011^{\mathrm{a} 3}[39.28]$ & $0.272 \pm 0.016^{\mathrm{a} 3}[47.42]$ & $0.212 \pm 0.013^{\mathrm{a} 3}[51.33]$ \\
\hline $\mathrm{CF} 100 \mathrm{mg} / \mathrm{kg}$ & $0.495 \pm 0.023^{\mathrm{b} 2}[7.77]$ & $0.518 \pm 0.026^{\mathrm{b} 2}[7.99]$ & $0.567 \pm 0.029^{\mathrm{b} 2}[7.10]$ & $0.490 \pm 0.028^{\mathrm{b} 3}[9.81]$ & $0.415 \pm 0.024^{\mathrm{b} 3 \mathrm{el}}[12.63]$ \\
\hline $\mathrm{CF} 200 \mathrm{mg} / \mathrm{kg}$ & $0.480 \pm 0.031^{\mathrm{b} 1}[10.60]$ & $0.512 \pm 0.038^{\mathrm{b} 2}[9.16]$ & $0.537 \pm 0.044^{\mathrm{b} 1}[12.02]$ & $0.427 \pm 0.025^{\mathrm{flb} 2}[21.50]$ & $0.343 \pm 0.025^{\mathrm{f} 2 \mathrm{~b} 2}[27.73]$ \\
\hline $\mathrm{CF} 400 \mathrm{mg} / \mathrm{kg}$ & $0.482 \pm 0.031^{\mathrm{b} 1}[10.20]$ & $0.500 \pm 0.022^{\mathrm{b} 1}[11.20]$ & $0.488 \pm 0.025[19.95]$ & $0.403 \pm 0.036^{\mathrm{f} 2 \mathrm{~b} 1}[25.80]$ & $0.288 \pm 0.030^{\mathrm{f} 3 \mathrm{bl} 1}[39.31]$ \\
\hline
\end{tabular}

Note: Values are expressed as Mean \pm S.E.M.; $\mathrm{n}=6$; Values in parenthesis shows \% inhibition of paw edema; ${ }^{a}$ compared with distilled $\mathrm{H}_{2} 0,{ }^{\mathrm{b}}$ compared with ASA $200 \mathrm{mg} / \mathrm{kg},{ }^{\mathrm{d}}$ compared with $200 \mathrm{mg} / \mathrm{kg}$ of respective fraction, ${ }^{\mathrm{e}}$ compared with $400 \mathrm{mg} / \mathrm{kg}$ of respective fraction, ${ }^{\mathrm{f}}$ compared with $2 \%$ tween $80 ;{ }^{1} p<0.05,{ }^{2} p<0.01,{ }^{3} p<0.001$; AF: aqueous fraction; BF: butanol fraction; CF: chloroform fraction.

Table 2. Effects of crude 70EE of Zehneria scabra on formaldehyde-induced arthritis in mice

\begin{tabular}{|c|c|c|c|c|c|}
\hline \multirow{2}{*}{ Treatment group } & \multicolumn{5}{|c|}{ Mean increase in paw volume $(\mathrm{mL}) \pm$ S.E.M and [\% Inhibition $(\% \mathrm{~A})]$} \\
\hline & Day 1 & Day 2 & Day 3 & Day 4 & Day 5 \\
\hline Distilled $\mathrm{H}_{2} \mathrm{O}$ & $0.450 \pm 0.029$ & $0.533 \pm 0.023$ & $0.645 \pm 0.024$ & $0.878 \pm 0.025$ & $0.887 \pm 0.028$ \\
\hline ASA $200 \mathrm{mg} / \mathrm{kg}$ & $0.347 \pm 0.029^{\mathrm{a} 1}[22.89]$ & $0.295 \pm 0.031^{\mathrm{a} 3}[44.65]$ & $0.238 \pm 0.025^{\mathrm{a} 3}[63.10]$ & $0.597 \pm 0.037^{\mathrm{a} 3}[32.00]$ & $0.550 \pm 0.028^{\mathrm{a} 3}[37.99]$ \\
\hline $70 \mathrm{EE} 100 \mathrm{mg} / \mathrm{kg}$ & $0.367 \pm 0.024[18.44]$ & $0.436 \pm 0.027^{\mathrm{b} 2}[18.20]$ & $0.480 \pm 0.024^{\mathrm{a} 2 \mathrm{~b} 3 \mathrm{dle} 2}[25.58]$ & $0.767 \pm 0.029^{\mathrm{b} 2 \mathrm{e} 2}[12.64]$ & $0.748 \pm 0.020^{\mathrm{alb} 3 \mathrm{e}^{2}}[15.67]$ \\
\hline $70 \mathrm{EE} 200 \mathrm{mg} / \mathrm{kg}$ & $0.353 \pm 0.010[21.56]$ & $0.398 \pm 0.016^{\mathrm{a} 1}[25.33]$ & $0.368 \pm 0.025^{\mathrm{a} 3 \mathrm{~b} 1}[42.95]$ & $0.666 \pm 0.031^{\mathrm{a} 3}[24.15]$ & $0.656 \pm 0.030^{\mathrm{a} 3}[26.04]$ \\
\hline \multirow[t]{2}{*}{$70 \mathrm{EE} 400 \mathrm{mg} / \mathrm{kg}$} & $0.332 \pm 0.026^{\mathrm{a} 1}[26.22]$ & $0.363 \pm 0.033^{\mathrm{a} 2}[31.89]$ & $0.307 \pm 0.031^{\mathrm{a} 3}[52.40]$ & $0.607 \pm 0.023^{\mathrm{a} 3}[30.87]$ & $0.578 \pm 0.032^{\mathrm{a} 3}[34.84]$ \\
\hline & Day 6 & Day 7 & Day 8 & Day 9 & Day 10 \\
\hline Distilled $\mathrm{H}_{2} \mathrm{O}$ & $0.808 \pm 0.031$ & $0.693 \pm 0.031$ & $0.642 \pm 0.033$ & $0.566 \pm 0.035$ & $0.477 \pm 0.034$ \\
\hline ASA $200 \mathrm{mg} / \mathrm{kg}$ & $0.512 \pm 0.025^{\mathrm{a} 3}[36.63]$ & $0.452 \pm 0.026^{\mathrm{a} 3}[34.85]$ & $0.400 \pm 0.025^{\mathrm{a} 3}[37.69]$ & $0.310 \pm 0.029^{\mathrm{a} 3}[45.23]$ & $0.232 \pm 0.028^{\mathrm{a} 3}[51.40]$ \\
\hline $70 \mathrm{EE} 100 \mathrm{mg} / \mathrm{kg}$ & $0.713 \pm 0.030^{\mathrm{b} 3 \mathrm{e} 3}[11.76]$ & $0.610 \pm 0.031^{\mathrm{b} 2 \mathrm{e} 3}[12.02]$ & $0.502 \pm 0.030^{\mathrm{a} 2 \mathrm{e} 3}[21.81]$ & $0.455 \pm 0.026^{\mathrm{ab2e} 3}[19.61]$ & $0.382 \pm 0.015^{\mathrm{alb} 2 \mathrm{e} 3}[19.92]$ \\
\hline $70 \mathrm{EE} 200 \mathrm{mg} / \mathrm{kg}$ & $0.607 \pm 0.018^{\mathrm{a} 3 \mathrm{e} 1}[24.88]$ & $0.518 \pm 0.014^{\mathrm{a} 2 \mathrm{e} 1}[25.24]$ & $0.460 \pm 0.016^{\mathrm{a} 3 \mathrm{e} 2}[28.35]$ & $0.383 \pm 0.009^{\mathrm{a} 3 \mathrm{e} 1}[32.33]$ & $0.308 \pm 0.016^{\mathrm{a} 3 \mathrm{e} 1}[35.33]$ \\
\hline $70 \mathrm{EE} 400 \mathrm{mg} / \mathrm{kg}$ & $0.487 \pm 0.033^{\mathrm{a} 3}[39.73]$ & $0.407 \pm 0.027^{\mathrm{a} 3}[41.34]$ & $0.322 \pm 0.018^{\mathrm{a} 3}[49.84]$ & $0.257 \pm 0.017^{\mathrm{a} 3}[54.59]$ & $0.188 \pm 0.019^{\mathrm{a} 3}[60.50]$ \\
\hline
\end{tabular}

Note: Values are expressed as Mean \pm SEM; $\mathrm{n}=6$; Values in parenthesis shows \% inhibition of paw edema (\% A); ${ }^{a}$ compared with distilled $\mathrm{H}_{2} 0,{ }^{\mathrm{b}}$ compared with $200 \mathrm{mg} / \mathrm{kg}$ ASA, ${ }^{\mathrm{d}} \mathrm{compared}$ 
Table 3. Effects of the solvent fractions of Zehneria scabra on formaldehyde-induced arthritis in mice

\begin{tabular}{|c|c|c|c|c|c|}
\hline \multirow{2}{*}{ Treatment group } & \multicolumn{5}{|c|}{ Mean increase in paw volume $(\mathrm{mL}) \pm$ S.E.M and [\% Inhibition $(\% \mathrm{~A})]$} \\
\hline & Day 1 & Day 2 & Day 3 & Day 4 & Day 5 \\
\hline Distilled $\mathrm{H}_{2} \mathrm{O}$ & $0.482 \pm 0.026$ & $0.558 \pm 0.023$ & $0.627 \pm 0.025$ & $0.832 \pm 0.017$ & $0.855 \pm 0.015$ \\
\hline $2 \%$ Tween & $0.515 \pm 0.031$ & $0.615 \pm 0.030$ & $0.640 \pm 0.019$ & $0.812 \pm 0.024$ & $0.827 \pm 0.021$ \\
\hline ASA $200 \mathrm{mg} / \mathrm{kg}$ & $0.363 \pm 0.027[24.58]$ & $0.308 \pm 0.032^{\mathrm{a} 3}[44.78]$ & $0.267 \pm 0.023^{\mathrm{a} 3}[57.44]$ & $0.643 \pm 0.025^{\mathrm{a} 2}[22.65]$ & $0.563 \pm 0.026^{\mathrm{a} 3}[34.12]$ \\
\hline $\mathrm{AF} 100 \mathrm{mg} / \mathrm{kg}$ & $0.383 \pm 0.029[20.43]$ & $0.262 \pm 0.028^{\mathrm{a} 3}[53.13]$ & $0.192 \pm 0.031^{\mathrm{a} 3}[69.41]$ & $0.600 \pm 0.045^{\mathrm{a} 3 \mathrm{e} 2}[27.86]$ & $0.580 \pm 0.047^{\mathrm{a3d} 2 \mathrm{e} 3}[32.16]$ \\
\hline $\mathrm{AF} 200 \mathrm{mg} / \mathrm{kg}$ & $0.408 \pm 0.045[15.24]$ & $0.258 \pm 0.026^{\mathrm{a} 3}[53.73]$ & $0.153 \pm 0.025^{\mathrm{a} 3 \mathrm{~b} 1}[75.54]$ & $0.492 \pm 0.026^{\mathrm{a} 3 \mathrm{~b} 1}[40.88]$ & $0.402 \pm 0.046^{\mathrm{a} 3 \mathrm{~b} 1}[53.02]$ \\
\hline $\mathrm{AF} 400 \mathrm{mg} / \mathrm{kg}$ & $0.393 \pm 0.025[18.35]$ & $0.235 \pm 0.031^{\mathrm{a} 3}[57.91]$ & $0.138 \pm 0.022^{\mathrm{a} 3 \mathrm{~b} 1}[77.93]$ & $0.447 \pm 0.027^{\mathrm{a} 3 \mathrm{~b} 2}[46.29]$ & $0.333 \pm 0.026^{\mathrm{a} 3 \mathrm{~b} 2}[61.02]$ \\
\hline $\mathrm{BF} 100 \mathrm{mg} / \mathrm{kg}$ & $0.425 \pm 0.031[11.77]$ & $0.372 \pm 0.034^{\mathrm{a} 2}[33.42]$ & $0.323 \pm 0.037^{\mathrm{a} 3}[48.41]$ & $0.715 \pm 0.038^{\mathrm{e} 1}[14.03]$ & $0.768 \pm 0.043^{\mathrm{b} 2 \mathrm{~d} 1 \mathrm{e} 3}[10.14]$ \\
\hline $\mathrm{BF} 200 \mathrm{mg} / \mathrm{kg}$ & $0.400 \pm 0.030[16.96]$ & $0.345 \pm 0.029^{\mathrm{a} 3}[38.21]$ & $0.280 \pm 0.025^{\mathrm{a} 3}[55.32]$ & $0.662 \pm 0.026^{\mathrm{a} 2}[20.44]$ & $0.617 \pm 0.026^{\mathrm{a} e \mathrm{e}} 1[27.87]$ \\
\hline $\mathrm{BF} 400 \mathrm{mg} / \mathrm{kg}$ & $0.387 \pm 0.030[19.72]$ & $0.288 \pm 0.028^{\mathrm{a} 3}[48.36]$ & $0.222 \pm 0.026^{\mathrm{a} 3}[64.62]$ & $0.578 \pm 0.034^{\mathrm{a} 3}[30.47]$ & $0.492 \pm 0.033^{\mathrm{a} 3}[42.49]$ \\
\hline $\mathrm{CF} 100 \mathrm{mg} / \mathrm{kg}$ & $0.455 \pm 0.016[11.65]$ & $0.525 \pm 0.023^{\mathrm{b} 3}[14.63]$ & $0.497 \pm 0.026^{\mathrm{f} 2 \mathrm{~b} 3}[22.39]$ & $0.737 \pm 0.022[9.24]$ & $0.720 \pm 0.030^{\mathrm{b} 2 \mathrm{e} 2}[12.91]$ \\
\hline $\mathrm{CF} 200 \mathrm{mg} / \mathrm{kg}$ & $0.445 \pm 0.032[13.59]$ & $0.522 \pm 0.030^{\mathrm{b} 3}[15.17]$ & $0.472 \pm 0.031^{\mathrm{f} 2 \mathrm{~b} 3}[26.3]$ & $0.695 \pm 0.029^{\mathrm{fi}}[14.38]$ & $0.672 \pm 0.029^{\mathrm{f} 2}[18.75]$ \\
\hline \multirow[t]{2}{*}{$\mathrm{CF} 400 \mathrm{mg} / \mathrm{kg}$} & $0.423 \pm 0.023[17.81]$ & $0.468 \pm 0.029^{\mathrm{fl} 1 \mathrm{~b} 2}[23.85]$ & $0.388 \pm 0.034^{\mathrm{f} 3 \mathrm{~b} 1}[39.33]$ & $0.627 \pm 0.037^{\mathrm{f2}}[22.79]$ & $0.567 \pm 0.033^{\mathrm{f} 3}$ \\
\hline & Day 6 & Day 7 & Day 8 & Day 9 & Day 10 \\
\hline Distilled $\mathrm{H}_{2} \mathrm{O}$ & $0.797 \pm 0.022$ & $0.715 \pm 0.027$ & $0.610 \pm 0.039$ & $0.522 \pm 0.034$ & $0.450 \pm 0.035$ \\
\hline $2 \%$ Tween & $0.758 \pm 0.020$ & $0.698 \pm 0.016$ & $0.600 \pm 0.017$ & $0.553 \pm 0.023$ & $0.492 \pm 0.031$ \\
\hline ASA $200 \mathrm{mg} / \mathrm{kg}$ & $0.498 \pm 0.026^{\mathrm{a} 3}[37.45]$ & $0.442 \pm 0.022^{\mathrm{a} 3}[38.22]$ & $0.370 \pm 0.019^{\mathrm{a} 3}[39.34]$ & $0.327 \pm 0.027^{\mathrm{a} 3}[37.38]$ & $0.262 \pm 0.024^{\mathrm{a} 3}[41.84]$ \\
\hline $\mathrm{AF} 100 \mathrm{mg} / \mathrm{kg}$ & $0.505 \pm 0.048^{\mathrm{a} 3 \mathrm{~d} 2 \mathrm{e} 3}[36.61]$ & $0.423 \pm 0.049^{\mathrm{a3d} 2 \mathrm{e} 3}[40.80]$ & $0.353 \pm 0.039^{\mathrm{a} 3 \mathrm{~d} 2 \mathrm{e} 3}[42.08]$ & $0.273 \pm 0.036^{\mathrm{a3d} 2 \mathrm{e} 2}[47.61]$ & $0.201 \pm 0.036^{\mathrm{azdle} 2}[55.18]$ \\
\hline $\mathrm{AF} 200 \mathrm{mg} / \mathrm{kg}$ & $0.315 \pm 0.037^{\mathrm{a} 3 \mathrm{~b} 2}[60.46]$ & $0.227 \pm 0.032^{\mathrm{a} b \mathrm{~b} 2}[68.29]$ & $0.172 \pm 0.027^{\mathrm{a} b \mathrm{~b} 2}[71.85]$ & $0.122 \pm 0.020^{\mathrm{a} 3 \mathrm{~b} 3}[76.67]$ & $0.078 \pm 0.015^{\mathrm{a} 3 \mathrm{~b} 3}[82.60]$ \\
\hline $\mathrm{AF} 400 \mathrm{mg} / \mathrm{kg}$ & $0.243 \pm 0.027^{\mathrm{a} 3 \mathrm{~b} 3}[69.46]$ & $0.185 \pm 0.017^{\mathrm{a} b 3}[74.13]$ & $0.132 \pm 0.013^{\mathrm{a} 3 \mathrm{~b} 3}[78.41]$ & $0.097 \pm 0.011^{\mathrm{a} 3 \mathrm{~b} 3}[81.46]$ & $0.052 \pm 0.010^{\mathrm{a} 3 \mathrm{~b} 3}[88.51]$ \\
\hline $\mathrm{BF} 100 \mathrm{mg} / \mathrm{kg}$ & $0.675 \pm 0.047^{\mathrm{b} 2 \mathrm{e} 3}[15.28]$ & $0.590 \pm 0.041^{\mathrm{bldle} 3}[17.48]$ & $0.518 \pm 0.041^{\mathrm{bldle} 3}[15.03]$ & $0.427 \pm 0.037^{\mathrm{e} 2}[18.21]$ & $0.347 \pm 0.037^{\mathrm{e} 2}[22.96]$ \\
\hline $\mathrm{BF} 200 \mathrm{mg} / \mathrm{kg}$ & $0.540 \pm 0.028^{\mathrm{a} 3}[32.22]$ & $0.457 \pm 0.029^{\mathrm{a} 3 \mathrm{e} 1}[36.13]$ & $0.373 \pm 0.033^{\mathrm{a} 3}[38.8]$ & $0.316 \pm 0.038^{\mathrm{a} 2}[39.29]$ & $0.262 \pm 0.030^{\mathrm{a} 2}[41.84]$ \\
\hline $\mathrm{BF} 400 \mathrm{mg} / \mathrm{kg}$ & $0.408 \pm 0.036^{\mathrm{a} 3}[48.75]$ & $0.330 \pm 0.028^{\mathrm{a} 3}[53.85]$ & $0.265 \pm 0.025^{\mathrm{a} 3}[56.56]$ & $0.220 \pm 0.022^{\mathrm{a} 3}[57.83]$ & $0.168 \pm 0.017^{\mathrm{a} 3}[62.6]$ \\
\hline $\mathrm{CF} 100 \mathrm{mg} / \mathrm{kg}$ & $0.657 \pm 0.031^{\mathrm{b} 2 \mathrm{e} 2}[13.40]$ & $0.592 \pm 0.038^{\mathrm{b} 2 \mathrm{e}^{2}}[15.27]$ & $0.483 \pm 0.037^{\text {flble } 3}[19.45]$ & $0.422 \pm 0.034^{\mathrm{fle} 3}[23.78]$ & $0.346 \pm 0.031^{\mathrm{f} 2 \mathrm{e}^{3}}[29.49]$ \\
\hline $\mathrm{CF} 200 \mathrm{mg} / \mathrm{kg}$ & $0.597 \pm 0.035^{\mathrm{f} 2 \mathrm{e} 1}[21.31]$ & $0.503 \pm 0.034^{\mathrm{f3} 3}[27.92]$ & $0.420 \pm 0.034^{\mathrm{f2e} 1}[30.00]$ & $0.368 \pm 0.035^{\mathrm{f} 2 \mathrm{e} 1}[33.44]$ & $0.302 \pm 0.027^{\mathrm{f3e} 2}[38.64]$ \\
\hline $\mathrm{CF} 400 \mathrm{mg} / \mathrm{kg}$ & $0.473 \pm 0.028^{\mathrm{f} 3}[37.58]$ & $0.406 \pm 0.026^{\mathrm{f3}}[41.76]$ & $0.286 \pm 0.020^{\mathrm{f} 3}[52.22]$ & $0.227 \pm 0.021^{\mathrm{f3} 3}[59.03]$ & $0.150 \pm 0.015^{\mathrm{f3b} 1}[69.49]$ \\
\hline
\end{tabular}

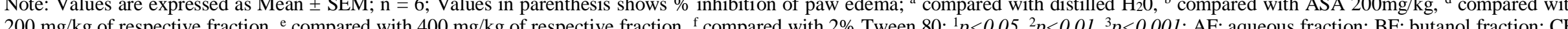
chloroform fraction 
Table 4. Effects of solvent fractions of Zehneria scabra on cotton pellet induced granuloma in rats

\begin{tabular}{|c|c|c|}
\hline Treatment group & $\begin{array}{l}\text { Mean weight of exudates }(\mathrm{mg}) \pm \text { S.E.M } \\
\text { and [\% inhibition] }\end{array}$ & $\begin{array}{c}\text { Mean weight of granuloma }(\mathrm{mg}) \pm \text { S.E.M } \\
\text { and [\% inhibition] }\end{array}$ \\
\hline Distilled $\mathrm{H}_{2} \mathrm{O}$ & $159.28 \pm 1.93$ & $32.61 \pm 0.76$ \\
\hline $2 \%$ Tween & $152.72 \pm 2.08$ & $34.2833 \pm 0.44$ \\
\hline Dexa $0.5 \mathrm{mg} / \mathrm{kg}$ & $87.50 \pm 2.05^{\mathrm{a} 3}[45.07]$ & $11.0917 \pm 0.44^{\mathrm{a} 3}[65.99]$ \\
\hline $\mathrm{AF} 100 \mathrm{mg} / \mathrm{kg}$ & $122.02 \pm 2.37^{\mathrm{a} 3 \mathrm{~b} 3 \mathrm{~d} 3 \mathrm{e} 3}[23.39]$ & $28.9333 \pm 0.83^{\mathrm{a} 2 \mathrm{~b} 3 \mathrm{e} 3}[11.27]$ \\
\hline $\mathrm{AF} 200 \mathrm{mg} / \mathrm{kg}$ & $99.81 \pm 1.91^{\mathrm{a} 3 \mathrm{~b} 2 \mathrm{e} 1}[37.34]$ & $26.3833 \pm 0.66^{\mathrm{a} b 3 \mathrm{~b} 3} 3[19.09]$ \\
\hline $\mathrm{AF} 400 \mathrm{mg} / \mathrm{kg}$ & $90.63 \pm 2.34^{\mathrm{a} 3}[43.10]$ & $21.3250 \pm 0.50^{\mathrm{a} \mathrm{b} \mathrm{b} 3}[34.61]$ \\
\hline $\mathrm{BF} 100 \mathrm{mg} / \mathrm{kg}$ & $152.23 \pm 1.77^{\mathrm{b} 3 \mathrm{e} 2}[4.43]$ & $30.6750 \pm 1.09^{\mathrm{b} 3}[5.93]$ \\
\hline $\mathrm{BF} 200 \mathrm{mg} / \mathrm{kg}$ & $150.82 \pm 1.58^{\mathrm{a} 1 \mathrm{~b} 3 \mathrm{e} 1}[5.31]$ & $29.6917 \pm 0.86^{\mathrm{b} 3}[8.95]$ \\
\hline $\mathrm{BF} 400 \mathrm{mg} / \mathrm{kg}$ & $142.21 \pm 1.29^{\mathrm{a} 3 \mathrm{~b} 3}[10.72]$ & $27.7483 \pm 0.65^{\mathrm{a} 2 \mathrm{~b} 3}[14.91]$ \\
\hline $\mathrm{CF} 100 \mathrm{mg} / \mathrm{kg}$ & $109.07 \pm 3.09^{\mathrm{f} 3 \mathrm{~b} 3 \mathrm{~d} 2 \mathrm{e} 3}[28.58]$ & $21.01 \pm 0.84^{\mathrm{f3b} 3 \mathrm{e} 3}[38.72]$ \\
\hline $\mathrm{CF} 200 \mathrm{mg} / \mathrm{kg}$ & $97.40 \pm 2.38^{\mathrm{f} 3 \mathrm{~b} 1}[36.22]$ & $18.85 \pm 0.59^{\mathrm{f} 3 \mathrm{~b} 3 \mathrm{e} 2}[45.02]$ \\
\hline $\mathrm{CF} 400 \mathrm{mg} / \mathrm{kg}$ & $88.61 \pm 0.95^{\mathrm{f3}}[41.98]$ & $15.25 \pm 0.66^{\mathrm{f3b} 2}[55.52]$ \\
\hline
\end{tabular}

Note: Values are expressed as Mean \pm S.E.M; $\mathrm{n}=6$; Values in parenthesis shows $\%$ inhibition $(\% \mathrm{~A}) ;{ }^{a}$ compared with distilled $\mathrm{H}_{2} 0{ }^{b}{ }^{\mathrm{b}}$ compared with dexa $0.5 \mathrm{mg} / \mathrm{kg},{ }^{\mathrm{d}}$ compared with $200 \mathrm{mg} / \mathrm{kg}$ of respective fraction, ${ }^{\mathrm{e}}$ compared with $400 \mathrm{mg} / \mathrm{kg}$ of respective fraction, ${ }^{\mathrm{f}}$ compared with $2 \%$ Tween $80 ;{ }^{1} p<0.05,{ }^{2} p<0.01,{ }^{3} p<0.001$; AF: aqueous fraction; BF: butanol fraction; CF: chloroform fraction; Dexa: dexamethasone.

Table 5. Preliminary phytochemical screening of $70 \mathrm{EE}$ and solvent fractions of Zehneria scabra

\begin{tabular}{|c|c|c|c|c|c|c|}
\hline $\begin{array}{l}\text { Secondary } \\
\text { metabolites }\end{array}$ & $\begin{array}{l}\text { Crude } \\
\text { 70EE }\end{array}$ & $\mathbf{A F}$ & BF & CF & $\begin{array}{c}\text { Distilled } \\
\text { water }\end{array}$ & $\begin{array}{c}2 \% \\
\text { Tween } \\
80\end{array}$ \\
\hline Alkaloids & + & ++ & + & - & - & - \\
\hline Tannins & + & + & ++ & - & - & - \\
\hline Saponins & + & ++ & - & - & - & - \\
\hline Terpenoids & + & ++ & + & - & - & - \\
\hline Steroids & + & - & - & ++ & - & - \\
\hline Flavonoids & + & - & - & ++ & - & - \\
\hline Anthraquinones & - & - & - & - & - & - \\
\hline Cardiac glycosides & ++ & + & + & - & - & - \\
\hline
\end{tabular}

Note: (+, Present); (-, Abscent); (++, relatively concentrated as compared to the crude extract)

In line with this notion, Akele (2012) has elucidated the anti-nociceptive and acute anti-inflammatory activity of the hydro-alcoholic crude leave extract of Z. scabra using the acetic acid-induced writhing test and carrageenin-induced edema model, respectively. Despite this, the literature recorded no reports about the anti-inflammatory activity of the crude extract and further fractions in experimental models of sub-acute and chronic inflammation. Thus, the present study is the first one to demonstrate the antiinflammatory activity of $70 \%$ ethanol leave extract and solvent fractions of $Z$. scabra using a battery of pharmacological inflammatory models ranging from acute to chronic ones.

The inflammatory response is a polyphasic tissue reaction, ranging from a temporary increase in vascular permeability to a prolonged cellular infiltration and proliferation. So, it is essential to evaluate the performance of agents claimed for anti-inflammatory effects via a battery of tests valid for various phases of inflammation (Kumar et al. 2012).

The carrageenan-induced paw edema model is a prototype of the exudative phase of acute inflammation
(Divakar et al., 2010; Sarkar, 2015). As a phlogistic agent, Carrageenan is not antigenic and is devoid of apparent systemic effect (Igbe and Inarumen 2013). Hence, carrageenan injection induces localized inflammation in two different phases through the subsequent release of several mediators. The initial period, which occurs between 0 and $2.5 \mathrm{~h}$ after carrageenan injection, has been attributed to the action of mediators such as histamine, serotonin, and bradykinin on vascular permeability. Histamine and serotonin are mainly released during the first $1.5 \mathrm{~h}$, while bradykinin is released from 1.5 to $2.5 \mathrm{~h}$ after carrageenan injection (Masresha et al. 2012).

The second phase (2.5 - $6 \mathrm{~h}$ post-carrageenan injection) is a result of the overproduction of COX-2 and its proinflammatory PG products, with infiltration of polymorphonuclear leukocytes (neutrophils) (Dawson et al. 1991; Coura et al. 2015). The peak inflammation is usually seen approximately $2-3 \mathrm{~h}$ post carrageenan injection and is attributed to PG release (Kumar et al., 2012; Silva-Neto et al., 2014). Hence, this second phase appears to be the most exciting in terms of inflammatory processes. The carrageenan-induced paw edema is known to be sensitive to COX inhibitors but not to 5- LOX inhibitors and hence has been used to evaluate the effect of NSAIDs, which primarily inhibit the COX pathway, i.e., single-action NSAIDs such as aspirin. It has been demonstrated that the suppression of carrageenin-induced hind paw edema after the $3^{\text {rd }} \mathrm{h}$ correlates reasonably with therapeutic doses of most clinically useful anti-inflammatory agents (Panthong et al., 2007; Mathew et al., 2014). Thence, in this study, carrageenan-induced hind paw edema was used as an appropriate acute inflammation model, and aspirin has opted as a reference drug.

The formaldehyde-induced arthritis model, on the other hand, represents a sub-acute phase characterized by increased migration of leukocytes and phagocytes to the area of inflammation (Divakar et al., 2010). Hence, the inhibition of formaldehyde-induced edema is one of the 
most suitable methods for evaluating the antiproliferative activity and screening anti-arthritic agents. Injection of formaldehyde into mice's hind paws produces localized inflammation and pain, which is biphasic. During the first neurogenic phase (0-5 min), pain is initiated due to the direct chemical stimulation of nociceptors. It is thought to be mediated by substance-P and bradykinin (Kaithwas et al., 2012; Sanusi et al., 2013). The second phase (15 min post-induction) appears to be an inflammatory phase during which histamine, serotonin, prostaglandin, and bradykinin become key mediators and thus could be inhibited by peripherally acting anti-inflammatory drugs such as aspirin. Leukocyte migration into the inflamed site will commence late in this phase $(2.5-6 \mathrm{~h})$ and is considered the most crucial inflammatory response process (Silva-Neto et al., 2014; Cui et al., 2014). In line with this notion, on the $1^{\text {st }}$ day of induction, paw edema was determined three $h$ following formaldehyde injection.

The cotton pellet-induced granuloma model is one of the most commonly employed models in animal research to screen for the chronic anti-inflammatory activity of drugs and novel natural products (Roome et al., 2014). In this model, the transudative phase causes an increase in the wet weight of the cotton pellet while hosting an inflammatory response to the implanted cotton between days $3-6$, causing granuloma formation due to the proliferation of fibroblasts and infiltration of modified macrophages and the lymphocytes. Hence, the increase in dry weight is considered a measure of chronic inflammation's proliferative component (Bagad et al., 2013). Therefore, this model was used to verify further the anti-inflammatory activity of solvent fractions of Z scabra on the transudative and proliferative components of chronic inflammation. Steroidal anti-inflammatory drugs demonstrated higher activity in this model (Andrade et al. 2007), and hence dexamethasone was opted as a reference drug.

The anti-inflammatory activity of hydroalcoholic crude leaf extracts of $Z$. scabra, in carrageenan-induced paw edema was reported by Akele (2012). In the present study, the anti-inflammatory potential of $70 \%$ ethanol crude leaves extract of $Z$. scabra was first tested against formaldehyde-induced arthritis, which is one of the most suitable test procedures to screen for the anti-arthritic and sub-acute anti-inflammatory activity of natural products as it closely resembles human arthritis (Deshpande et al. 2011). In this model, the crude $70 \mathrm{EE}$ at 200 and $400 \mathrm{mg} / \mathrm{kg}$ doses demonstrated statistically significant inhibition of paw edema from day two to day 10 of treatment compared to the negative control (Table 2). In addition, $400 \mathrm{mg} / \mathrm{kg}$ of $70 \mathrm{EE}$ showed a comparable anti-inflammatory effect $(\% \mathrm{~A})$ with $200 \mathrm{mg} / \mathrm{kg}$ of aspirin. This could be due to certain alterations in the inflammatory response with possible antiarthritic potential comparable with the standard drug aspirin.

Furthermore, the result was also in agreement with the anti-inflammatory effects of the hydroalcoholic crude extract on carrageenan-induced acute inflammation, as reported by Akele (2012), and expands the evidence of its anti-arthritic and anti-proliferative efficacy on the subacute model of inflammation. The result obtained for the
$70 \mathrm{EE}$ in formaldehyde induced arthritis model was also in line with those reported elsewhere (Umukoro and Ashorobi 2006; Deshpande et al. 2011; Reddy et al. 2015), where extracts of Momordica charantia, Coccinia grandis, and Momordica cymbalaria showed statistically significant inhibition of formaldehyde induced paw edema, signifying the potential anti-arthritis and anti-proliferative activity of plants in the Cucurbitaceae family.

Besides, for further evaluation of the nature of the active constituents and to state the possible mechanism(s) of the anti-inflammatory activity of the plant, the 70EE was successively fractionated by partitioning into solvents of differing polarity, and the anti-inflammatory activity of the fractions was evaluated by using acute, sub-acute and chronic models of inflammation.

The aqueous fraction (AF), at all tested doses, showed statistically significant inhibition of inflammatory parameters in all three employed models of inflammation. In the acute model (carrageenan-induced paw edema), all employed doses of the AF showed a significant $(\mathrm{p}<0.01$ and $\mathrm{p}<0.001$ ) inhibition of paw edema starting from $1 \mathrm{~h}$ post-induction, and the effect was maintained till the $5^{\text {th }} \mathrm{h}$ (Table 1). The significant anti-inflammatory activity of this fraction during the first 2 hours of the initial phase of inflammation could be due to the inhibitory effect on mediators like histamine and 5-HT. This is further evidenced by the higher inhibitory effect of all doses of the AF compared to the particular time the inhibitory effect of aspirin, which like most other NSAIDs, has less effect on the first phase of carrageenan-induced inflammation. No significant increment in percent inhibition values of all tested doses of the AF was noted from the $2^{\text {nd }}$ to the $3^{\text {rd }} \mathrm{h}$. As noted above, this is the period where the release of the mediator bradykinin reaches its peak. Hence, it can be generalized that the AF may not have a significant inhibitory effect on the release or activity of bradykinin.

Furthermore, all tested doses of the AF showed more pronounced edema inhibition in the second phase of inflammation on the $4^{\text {th }}$ and $5^{\text {th }} \mathrm{h}$, compared to their respective inhibitory values in the first phase $(0-2.5 \mathrm{~h})$, achieving the maximum anti-inflammatory effect on the $5^{\text {th }}$ $\mathrm{h}$. This indicates that the primary mechanism of the antiinflammatory effect of the AF could be via inhibition of COX and its pro-inflammatory metabolites, such as PGs. This is substantiated by the fact that even the lower employed dose of the AF $(100 \mathrm{mg} / \mathrm{kg})$ showed a comparable inhibitory effect with that of aspirin, which like most other NSAIDs, exert a more pronounced effect on the second phase (Panthong et al. 2007; Mathew et al. 2014). Moreover, the higher employed doses, 200 and $400 \mathrm{mg} / \mathrm{kg}$, of the AF even showed a better inhibitory effect than aspirin in this late phase of inflammation, which is primarily mediated through products of the inducible COX.

This finding is also in line with Akele's (2012) previous report. The crude hydroalcoholic extract of Z.scabra showed significant inhibition of carrageenan-induced paw edema in the second phase of inflammation, with the maximum effect observed at the $3^{\text {rd }} \mathrm{h}$. In comparison with Akele's (2012) report on the crude extract, it could be concluded that the phytochemicals responsible for the 
pronounced anti-inflammatory effect on the second phase of acute inflammation could be highly concentrated in the $\mathrm{AF}$. This could be explained since the equivalent doses of the crude extract showed a better percent inhibition value in the first phase ( $\sim$ up to the $3^{\text {rd }} \mathrm{h}$ ) than treatments of the $\mathrm{AF}$ at a given point of time; whereas from the $3^{\text {rd }}$ to $5^{\text {th }} \mathrm{h}$ of the second phase, all tested doses of the AF showed a remarkably higher percent inhibition than the equivalent doses of the crude extract at the respective point of time. This could be possibly due to preferential partitioning of the secondary metabolites responsible for a better antiinflammatory effect on the second phase, perhaps through COX inhibition, into the AF.

The results from the sub-acute and chronic models also revealed the anti-inflammatory effects of this fraction. For example, in the cotton pellet-induced granuloma model, all tested doses of the AF showed statistically significant inhibition of both exudates and granuloma formation. In this model, the vital $(\mathrm{P}<0.001)$ inhibitory effect of the AF on the formation of exudates (Table5) substantiates the finding of the carrageenan-induced acute model, i.e., both findings solidify the effectiveness of the AF in inhibiting the exudative and transudative component of inflammation. On the other hand, the statistically significant $(\mathrm{P}<0.01$ and $\mathrm{P}<0.001$ ) inhibition of granuloma formation justifies the effectiveness of this fraction in inhibiting the proliferative phase of inflammation. This could also be ascertained from the findings of the formaldehyde-induced arthritic model, in which all tested doses of the AF significantly ( $p$ $<0.001$ ) inhibited the development of arthritis from day 2 to 10 of treatment (Table 3). Moreover, the AF at all tested doses demonstrated a considerably better inhibitory effect on formaldehyde-induced arthritis as compared to equivalent doses of the crude 70EE (Table 2) from day two throughout to day 10 of treatment. This could be possibly due to preferential partitioning of the secondary metabolites responsible for a better anti-arthritic activity in the AF.

Phytochemical screening for secondary metabolites revealed the presence of alkaloids, saponins, tannins, and terpenoids in the aqueous residue. The anti-inflammatory activity of this fraction could emanate from the presence of these secondary metabolites whose protection against inflammation is also reported elsewhere; alkaloids (Küpeli et al. 2002; Souto et al. 2011), saponins (Navarro et al. 2001; Ahn et al. 2005; Chen et al. 2014), and terpenoids (Heras and Hortelano 2009; Bellik et al. 2012; Ku and Lin 2013).

The mechanism of the anti-inflammatory effect of these different secondary metabolites is also documented in the literature. Various terpenoids were reported to exert their anti-inflammatory influence by inhibiting PLA2 activity, inhibition of TNF- $\alpha$ production, inhibition of iNOS expression, inhibition of COX-2 expression, and inhibition of NF- $\kappa B$ activation (Bellik et al. 2012). Saponins were also reported to exert an anti-inflammatory effect by inhibiting iNOS expression, COX-2 expression, and subsequent production of PGE2 (Ahn et al. 2005). The anti-inflammatory activity of different alkaloids was also reported to be mediated through inhibition of $\mathrm{COX}$ expression and production of PGE2 (Fukuda et al. 1999; Kuo et al. 2004), inhibition of pro-inflammatory cytokines production (IL-1 $\beta$, IL-6, TNF- $\alpha$ ) and inhibition of the expression of ICAM-1 and VCAM-1 adhesion molecules (Bellik et al. 2012).

From the results of the phytochemical screening, terpenoids were found to be highly concentrated in the AF, less in the BF, and none in the CF. Polar solvents such as ethanol and water led to the extraction of highly oxygenated polar triterpenes and triterpenoid glycosides. In contrast, non-polar solvents such as chloroform and petroleum ether extracted most other lipid-soluble terpenoids such as Sesquiterpene lactones, diterpenes, and sterols (Citoglu and Acikara 2012). From this fact and the findings of the phytochemical screening, highly oxygenated polar triterpenes or triterpenoid glycosides could be the significant terpenoids concentrated in the AF and responsible for their anti-inflammatory activity. This could further be substantiated by a lack of activity of the petroleum ether extract in the pilot study and the negative terpenoid test result of the $\mathrm{CF}$ for the lipid-soluble terpenoids.

Other plants in the Cucurbitaceae family such as Cayaponia tayuya (Escandell et al. 2007), Cucurbita andreana (Jayaprakasam et al. 2003), Picrorhiza scrophulariaeflora (Smit et al. 2000), Wilbrandia ebracteata (Peters et al. 1999), and Citrullus lanatus (Abdelwahab et al. 2011), were also reported to contain highly oxygenated triterpenoid molecules called cucurbitacins, which were proved to have potent antiinflammatory and anti-proliferative activities (Wakimoto et al. 2008; Duangmano et al. 2012).

All in all, from the results of the acute (Table 1) and sub-acute (Table 3 ) models of inflammation and percentage inhibition values of exudate formation in the chronic model (Table 4), the AF was found to be the most active fraction in inhibiting the exudative and transudative component of inflammation. It was also found to exhibit significant antiproliferative activity, as revealed by the results of the subacute model (Table 3 ) and percentage inhibition values of granuloma formation in the chronic granulomatous inflammatory model (Table 4).

Moreover, the probable mechanism of the antiinflammatory effect of the phytochemicals concentrated in the AF could be explained by inhibiting mediators like histamine, serotonin, and products of $\mathrm{COX}$, such as proinflammatory PGs. The latter mechanism, i.e., inhibition of COX, could be the primary mechanism of the antiinflammatory effect of this fraction since it showed a more significant effect during the second phase of the acute model of inflammation. This is further substantiated by the type of secondary metabolites found in this fraction, most of which were proved to possess COX inhibitory activities.

The butanol fraction (BF), at doses of 200 and $400 \mathrm{mg} / \mathrm{kg}$, significantly inhibited mice paw edema in both acute (Table 1) and sub-acute (Table 3) models of inflammation. In the cotton pellet-induced granuloma model, on the other hand, only the highest tested dose $(400 \mathrm{mg} / \mathrm{kg})$ showed statistically significant inhibition of both inflammatory exudates $(\mathrm{P}<0.001)$ and granuloma 
formation $(\mathrm{P}<0.01)$. A phytochemical test (Table 5) of this fraction revealed the presence of tannins, alkaloids, and terpenoids, albeit the last two secondary metabolites with a relatively lower concentration than the AF.

The moderate anti-inflammatory effect of the $\mathrm{BF}$ in the acute and sub-acute model, compared to the AF, could be accounted for by the presence of alkaloids and terpenoids, which were the main constituents of the most active AF. The anti-inflammatory effect of the BF could also emanate from tannins, the primary concentrate. The antiinflammatory effect of tannins was reported to be mediated through inhibition of leukocyte migration by their wellknown astringent properties, which cause precipitation of cell membrane proteins and hence affect cellular movements, recruitment, and membrane permeability (Mota et al. 1985) and/or through inhibition of expression of pro-inflammatory cytokines and chemokines by blocking of transcription factors, NF- $\kappa \mathrm{B}$ and AP-1 (Erdèlyi et al. 2005). These different mechanisms underlying tannins may at least partly be responsible for the moderate anti-inflammatory effect observed for higher doses of the $\mathrm{BF}$ in inhibition of edema (carrageenan and formaldehydeinduced edema models) and cellular proliferation in the chronic model.

Unlike the $\mathrm{AF}$ and $\mathrm{BF}$, the higher doses of chloroform fraction (200 and $400 \mathrm{mg} / \mathrm{kg}$ CF) showed a statistically significant anti-inflammatory effect only during the second phase $\left(4^{\text {th }}\right.$ and $\left.5^{\text {th }} \mathrm{h}\right)$ of carrageenan-induced paw edema (Table 1). Similarly, the anti-inflammatory effect of this fraction was delayed until the $3^{\text {rd }}$ day of formaldehydeinduced arthritis. This could probably be due to the specific inhibitory effect of phytochemicals in the $\mathrm{CF}$ on the synthesis or outcome of pro-inflammatory PGs, which mainly mediate the late phase of carrageenan-induced paw edema.

In the cotton pellet-induced granuloma model, on the other hand, the $\mathrm{CF}$ at all employed doses showed a comparable inhibitory effect on exudate formation with the equivalent doses of the $\mathrm{AF}$ (Table 4). Moreover, in this model, the CF at all treatments was found to be the most active fraction of inhibition of granuloma formation, the maximum inhibitory effect $(\% \mathrm{~A}=55.52, \mathrm{p}<0.001)$ being observed at a dose of $400 \mathrm{mg} / \mathrm{kg}$. From these findings, i.e., the delayed anti-inflammatory effect in the acute and subacute model and its profound inhibitory effect on granuloma formation in the chronic model, it can be concluded that the CF's phytochemicals may be most effective in inhibiting pro-inflammatory prostanoids and cytokines induced cellular proliferation.

The results of the phytochemical screening revealed the preferential partitioning of steroids and flavonoids into the CF. Different kinds of literature support the antiproliferative efficacy of these phytochemicals; Loizou et al. (2009) and Bigoniya et al. (2013), for example, showed phytosterols to inhibit TNF- $\alpha$ induced endothelial activation and expression of ICAM-1 and VCAM-1 adhesion molecules which mediate cellular recruitment to sites of inflammation. Hernández-Valle et al. (2014), Han et al. (2015), and Wagle et al. (2016), on the other hand, showed phytosterols to inhibit the inflammatory cytokines
IL-6, IL-1 $\beta$, TNF- $\alpha$, and on the contrary induce the production of anti-inflammatory cytokines IL-4 and IL-10.

On the other hand, Flavonoids were reported to exhibit anti-inflammatory and anti-proliferative effects through selective inhibition of 5-LOX (Schewe et al. 2002; Redrejo-Rodriguez et al. 2004), COX-2, and/or iNOS (Tunon et al. 2009). Aquila et al. (2009) further reported the anti-inflammatory effect of flavonoids from Cayaponia tayuya (Cucurbitaceae) to be mediated through inhibition of COX-2 and iNOS induction. The possibility of selective COX-2 inhibition by flavonoids in the CF is further evidenced by the delayed anti-inflammatory effect shown in the second phase of the acute model.

The major products of the 5-LOX pathway, LTB4, and CysLTs, in concert with the adhesion molecules ICAM-1 and VCAM-1, are known to mediate chemokinesis, firm adhesion, and subsequent extravasation of leucocytes to sites of inflammation (Werz et al. 2002; Pelletier et al. 2003; Weber et al. 2007; Afonso et al. 2012). On the other hand, products of the COX pathway, especially PGE2 and PGI2, are well known for their potent vasodilatory actions and increasing vascular permeability and leukocyte infiltration (Pelletier et al., 2003; Smyth et al., 2009). Hence, the effectiveness of the $\mathrm{CF}$ in inhibiting the formation of inflammatory exudates and, more profoundly, granuloma in the chronic model could emanate from the possible inhibitory effect of the flavonoids and phytosterols on the COX and 5-LOX pathways and/or inhibition of inflammatory cytokines induced endothelial activation and expression of ICAM-1 and VCAM-1.

All in all, the results of this study revealed that the crude extract (70EE) and solvent fractions of Z.scabra leaves possess anti-inflammatory activities. The overall order of efficacy in inhibiting the exudative phase of acute inflammation, as evidenced by the percentage inhibition of paw edema in the critical model, was found to be $\mathrm{AF}>\mathrm{BF}$ $>\mathrm{CF}$. Hence the phytochemicals in the AF could be most effective in inhibiting the acute phase of inflammation. While on the contrary, the overall order of effectiveness in inhibiting the proliferative phase of chronic inflammation, as evidenced by the percentage of granuloma inhibition in the chronic model, was found to be $\mathrm{CF}>\mathrm{AF}>\mathrm{BF}$. This indicates that the phytochemicals concentrated in the $\mathrm{CF}$ may be specifically useful in inhibiting the cellular response of the proliferative phase of inflammation.

Such disparity in order of effectiveness of the fractions in modulating the acute and chronic phases of inflammation could be due to the differential partitioning of phytochemicals into the three portions (Table 5) and the associated difference in the mechanism of action of the secondary metabolites. Furthermore, the greater efficacy of the AF in comparison with other fractions in inhibiting the acute phase of inflammation supports the traditional method of extraction of the leaves of Z.scabra in Ethiopia, where the leaves are boiled in water, and the vapor inhaled, or they leave juice is given orally for the treatment of inflammatory conditions (Teklehaymanot and Giday 2007; Ragunathan and Abay 2009; Birhanu 2013).

From the overall results of this study, it can be postulated that $Z$. scabra is rich in secondary anti- 
inflammatory metabolites that act by different mechanisms to inhibit acute, sub-acute, and chronic inflammatory conditions. Moreover, the potent anti-inflammatory activity of the 70EE and solvent fractions of Z. scabra in this study as compared to the standard drug aspirin may be due to the cumulative effects of different active constituents in reducing the synthesis, release, and/or action of various inflammatory cytokines, chemokines and mediators such as histamine, serotonin, prostaglandins, and Leukotrienes. This notion is in line with the proven concept that medicinal plants possess a combination of phytoconstituents with different anti-inflammatory mechanisms, offering synergistic or additive effects (Liu 2003; Csaki et al. 2009).

The phytochemical screening in the present study revealed the presence of secondary metabolites such as alkaloids, tannins, saponins, terpenoids, steroids, flavonoids, and cardiac glycosides in the crude 70EE and their differential partitioning into employed solvents of differing polarity (Table 5). Tesfaye and Alamneh (2014) reported the absence of saponins in the crude $80 \%$ methanol extract of the leaves of $Z$. scabra. However, the test for other secondary metabolites was in line with the present study's findings. On the other hand, Tadesse et al. (2014) reported the presence of saponins, which is in agreement with the results of the present study, while Alkaloids and steroids were tested negative in $80 \%$ methanolic leaves extract of Z. scabra. Such discrepancy in the presence and/or absence of secondary metabolites could be accounted for by seasonal and geographical variations, which are known to influence the expression of phytochemical constituents in plants (Jayanthy et al., 2013).

Arulappan et al. (2015), conversely, showed the presence of phenolic compounds, steroids, and glycosides and the absence of tannins, flavonoids, alkaloids, and saponins in the ethanolic (absolute) and aqueous tuber extract of Z.scabra. Such disagreement with the present study results could be due to the differential distribution of the secondary metabolites into different parts of the plant, i.e., the tuber and leaves, on top of the geographic variation and the difference in the extraction solvents.

In this study, ethanol specifically was chosen as the solvent of extraction as it can extract a wide variety of polar and nonpolar phytochemical constituents in medicinal plants (Herman et al., 2013; Tatke and Rajan, 2014). Hydroalcoholic solvents (a mixture of alcohol and water in varying proportions) are generally considered to give high extraction yields, owing to their expanded polarity range (Gupta et al. 2012). It is also hypothesized that alcoholic solvents efficiently penetrate the cell membranes, permitting the extraction of high amounts of endocellular components, including phytochemicals produced in plants. Furthermore, ethanol is widely used to obtain crude extracts of phytochemicals in the herbal medicine industry for therapeutic applications due to its relative safety (Wendakoon et al., 2012). Hence, 70\% v/v ethanol was the solvent of choice in the present study for extracting the leaves of Z. scabra.
Moreover, male mice and rats were preferably used in this study for all the anti-inflammatory models. The rationale for using the male sex in inflammation models is because estrogen, the primary female sex hormone, has been confirmed to possess anti-inflammatory activity by a line of evidence (Miyamoto et al. 1999; Cuzzocrea et al. 2000; Vegeto et al. 2002).

The results of phytochemical tests revealed that leaves of Z.scabra are chemically enriched with alkaloids, tannins, saponins, terpenoids, steroids, flavonoids, and cardiac glycosides. The results from the pharmacological tests further confirmed the aqueous fraction to be the most efficient fraction in inhibiting the exudative component of acute inflammation. In contrast, the chloroform fraction showed the highest activity in inhibiting the cellular response of the proliferative part of chronic inflammation. On the other hand, the butanol fraction was found to possess a moderate activity in both the acute (carrageenaninduced) and sub-acute (formalin-induced) paw edema models and was found to be the least active in the cotton pellet-induced chronic granuloma model.

In conclusion, the data obtained in this study demonstrated that the leaves of Z.scabra possess different secondary metabolites, which, by acting through an array of possibly different mechanisms, are useful in treating both acute and chronic inflammatory conditions. The current findings also demonstrated the scientific rationale for the traditional use of this plant in different inflammatory conditions. It also confirms the presence of biologically active components, which are worth further investigation and elucidation.

\section{REFERENCES}

Abdelwahab SI, Hassan LEA, Sirat HM, Yagi SMA, Koko WS, Mohan S, Taha MME, Ahmad S, Chuen CS, Narrima P, Rais MM. 2011. Antiinflammatory activities of cucurbitacin E isolated from Citrullus lanatus var. citroides: role of reactive nitrogen species and cyclooxygenase enzyme inhibition. Fitoterapia 82 (8): 1190-1197. DOI: 10.1016/j.fitote.2011.08.002.

Afonso PV, Janka-Junttila M, Lee YJ, McCann CP, Oliver CM, Aamer KA, Losert W, Cicerone MT, Parent CA. 2012. LTB 4 is a signalrelay molecule during neutrophil chemotaxis. Dev Cell 22 (5): 10791091. DOI: 10.1016/j.devcel.2012.02.003.

Afsar SK, Kumar KR, Gopal JV, Raveesha P. 2013. Assessment of antiinflammatory activity of Artemisia vulgaris leaves by cotton pellet granuloma method in Wistar albino rats. J Pharm Res 7: 463-467. DOI: 10.1016/j.jopr.2013.04.056.

Ahn KS, Noh EJ, Zhao HL, Jung SH, Kang SS, Kim YS. 2005. Inhibition of inducible nitric oxide synthase and COX-II by Platycodon grandiflorum saponins via suppression of nuclear factor- $\kappa \mathrm{B}$ activation in RAW 264.7 cells. Life Sci 76 (20): 2315-2328. DOI: 10.1016/j.lfs.2004.10.042.

Akele B. 2012. In vivo anti-inflammatory and antinociceptive activities of aerial part extracts of Zehneria scabra. Intl J Pharm Ind Res 2 (4): 479-484.

Anand SP, Doss A, Jeyachandran R. 2012. antagonistic microbial screening of shoot extracts of Zehneria scabra (Lf) Sonder. IJRAP 3 (1): 109-111.

Andrade SF, Cardoso LGV, Carvalho JCT, Bastos JK. 2007. Antiinflammatory and antinociceptive activities of extract, fractions and populnoic acid from bark wood of Austroplenckia populnea. J Ethnopharmacol 109 (3): 464-471. DOI: 10.1016/j.jep.2006.08.023.

Aquila S, Giner RM, Recio MC, Spegazzini ED, Ríos JL. 2009. Antiinflammatory activity of flavonoids from Cayaponia tayuya roots. Ethnopharmacol 121 (2): 333-337. DOI: 10.1016/j.jep.2008.11.002. 
Arulappan TM, Britto JS, Ruckmani K, Kumar MR. 2015. Antimicrobial and antifungal activities of Zehneria scabra (L.F.) sond against human pathogens. Int J Dev Res 5 (3): 3852-3859.

Aziz TA, Marouf1 BH, Ahmed ZA, Hussain SA. 2014. Antiinflammatory activity of Silibinin in animal models of chronic inflammation. Am J Pharmacol Sci 2 (1): 7-11. DOI: 10.12691/ajps2-1-2.

Bagad AS, Joseph JA, Bhaskaran N, Agarwal A. 2013. Comparative evaluation of anti- inflammatory activity of curcuminoids, turmerones, and aqueous extract of Curcuma longa. Adv Pharmacol Sci 2013. DOI: 10.1155/2013/805756.

Bellik Y, Boukraâ L, Alzahrani HA, Bakhotmah BA, Abdellah F, Hammoudi SM, Iguer-Ouada M. 2012. Molecular mechanism underlying anti-inflammatory and anti-allergic activities of phytochemicals: an update. Molecules 18 (1): 322-353. DOI 10.3390/molecules18010322.

Bigoniya P, Thakur AS, Singh S. 2013. Analgesic, anti-inflammatory and anti-arthritic activity of Euphorbia thymifolia Linn phytosterol fraction. BioMedRx 1 (2): 130-134.

Birhanu Z. 2013. Traditional use of medicinal plants by the ethnic groups of Gondar Zuria District, North-western Ethiopia. J Nat Remedies 13 (1): 46-53.

Chen YQ, Rong L, Qiao JO. 2014. Anti-inflammatory effects of Panax notoginseng saponins ameliorate acute lung injury induced by oleic acid and lipopolysaccharide in rats. Mol Med Rep 10 (3): 1400-1408. DOI: $10.3892 / \mathrm{mmr} .2014 .2328$.

Citoglu GS, Acikara OB. 2012. Column Chromatography for Terpenoids and Flavonoids. Chromatography and Its Applications. Intech, Rijeka, Croatia.

Coura CO, Souza RB, Rodrigues JAG, Vanderlei EDSO, de Araújo IWF, Ribeiro NA, Frota AF, Ribeiro KA, Chaves HV, Pereira KMA, da Cunha RMS. 2015. Mechanisms involved in the anti-inflammatory action of a polysulfated fraction from Gracilaria cornea in Rats. PloS One 10 (3): e0119319. DOI: 10.1371/journal.pone.0119319

Csaki C, Mobasheri A, Shakibaei M. 2009. Synergistic chondroprotective effects of curcumin and resveratrol in human articular chondrocytes: inhibition of IL-1 $\beta$-induced NF- $\kappa$ B- mediated inflammation and apoptosis. Arthritis Res Ther 11 (6). DOI: 10.1186/ar2850.

Cui E, Zhi X, Chen Y, Gao Y, Fan Y., Zhang W, Ma W, Hou W, Guo C, Song X. 2014. Coptis chinensis and Myrobalan (Terminalia chebula) can synergistically inhibit inflammatory response in vitro and in vivo. Evidence-Based Complement Altern Med 2014. DOI: 10.1155/2014/510157.

Cuzzocrea S, Santagati S, Sautebin L, Mazzon E, Calabrò G, Serraino I, Caputi AP, Maggi A. 2000. 17ß-estradiol antiinflammatory activity in carrageenan-induced pleurisy. Endocrinology 141 (4): 1455-1463. DOI: 10.1210/endo.141.4.7404

Dawson J, Sedgwick AD, Edwards JC, Lees P. 1991. A comparative study of the cellular, exudative and histological responses to carrageenan, dextran and zymosan in the mouse. Intl J Tissue React 13 (4): 171185 .

Debella A. 2002. Manual for phytochemical screening of medicinal plants. Ethiopian Health and Nutrition Research Institute, Addis Ababa, Ethiopia.

Deshpande SV, Patil MJ, Daswadkar SC, Suralkar U, Agarwal A. 2011. A study on anti- inflammatory activity of the leaf and stem extracts of Coccinia grandis L. Voigt. Intl J Appl Biol Pharm Technol 2 (3): 247-250.

Divakar CM, Sheela S, Sandhya S, Vinod KR, Pillai NR, Rao SB. 2010. Anti- inflammatory and antioxidant activities of Polyscias filicifolia saponins. Der Pharmacia Lett 2 (1): 41-47.

Duangmano S, Sae-lim P, Suksamrarn A, Domann FE, Patmasiriwat P. 2012. Cucurbitacin B inhibits human breast cancer cell proliferation through disruption of microtubule polymerization and nucleophosmin/B23 translocation. BMC Compl Altern Med 12 (1): 185. DOI: 10.1186/1472-6882-12-185

Erdèlyi K, Kiss A, Bakondi E, Bai P, Szabó C, Gergely P, Erdödi F, Virág L. 2005. Gallotannin inhibits the expression of chemokines and inflammatory cytokines in A549 cells. Mol Pharmacol 68 (3): 895904. DOI: 10.1124/mol.105.012518

Escandell JM, Recio MC, Máñez S, Giner RM, Cerdá-Nicolás M, Ríos JL. 2007. Cucurbitacin $\mathrm{R}$ reduces the inflammation and bone damage associated with adjuvant arthritis in Lewis rats by suppression of tumor necrosis factor- $\alpha$ in $\mathrm{T}$ lymphocytes and macrophages. J Pharmacol Exp Ther 320 (2): 581-590. DOI: 10.1124/jpet.106.107003
Fukuda K, Hibiya Y, Mutoh M, Koshiji M, Akao S, Fujiwara H. 1999. Inhibition by berberine of cyclooxygenase-2 transcriptional activity in human colon cancer cells. J Ethnopharmacol 66 (2): 227-233. DOI: 10.1016/S0378-8741(98)00162-7.

Gupta A, Naraniwal M, Kothari V. 2012. Modern extraction methods for preparation of bioactive plant extracts. Intl J Appl Nat Sci 1 (1): 8-26. DOI: $10.1186 / 1746-4811-8-26$.

Han NR, Kim HM, Jeong HJ. 2015. The potential anti-proliferative effect of $\beta$-sitosterol on human mast cell line-1 cells. Can J Physiol Pharmacol 93 (11): 979-983. DOI: 10.1139/cjpp-2015-0166.

Heras B, Hortelano S. 2009. Molecular basis of the anti-inflammatory effects of terpenoids. Inflamm Allergy-Drug Targets 8 (1): 28-39. DOI: $10.2174 / 187152809787582534$

Herman HP, Darnis DS, Saad S, Bakhtiar MT, Ramli N. 2013. Wound healing properties of ethanolic extract of Acrostichum aureum and Acrostichum speciosum rhizome in rats. J Trop Resour Sustain Sci 1 (2): 42-48.

Hernández-Valle E, Herrera-Ruiz M, Salgado GR, Zamilpa A, Ocampo MLA, Aparicio AJ, Tortoriello J, Jiménez-Ferrer E. 2014. Antiinflammatory effect of 3-O-[(6'-O- palmitoyl)- $\beta$-D-glucopyranosyl sitosterol] from Agave angustifolia on ear edema in mice. Molecules 19 (10): 15624-15637. DOI: 10.3390/molecules191015624.

Igbe I, Inarumen GO. 2013. The effect of leaf aqueous extract of Brachystegia eurycoma harms (fabaceae) in acute and chronic inflammatory animal models. Br J Pharm Res 3 (3): 391-400. DOI: 10.9734/BJPR/2013/2922.

Jayanthy A, Kumar PU, Remashree AB. 2013. Seasonal and geographical variations in cellular characters and chemical contents in Desmodium gangeticum (L.) DC.-an ayurvedic medicinal plant. Int J Herbal Med 2 (3): 34-37.

Jayaprakasam B, Seeram NP, Nair MG. 2003. Anticancer and antiinflammatory activities of cucurbitacins from Cucurbitaandreana. Cancer Lett 189 (1): 11-16. DOI: 10.1016/S0304-3835(02)00497-4.

Kaithwas G, Gautam R, Jachak SM, Saklani A. 2012. Antiarthritic effects of Ajuga bracteosa Wall ex Benth. in acute and chronic models of arthritis in albino rats. Asian Pac J Trop Biomed 2 (3): 185-188. DOI: 10.1016/S2221-1691(12)60039-2.

$\mathrm{Ku}$ CM, Lin JY. 2013. Anti-inflammatory effects of 27 selected terpenoid compounds tested through modulating Th1/Th2 cytokine secretion profiles using murine primary splenocytes. Food Chem 141 (2): 11041113. DOI: 10.1016/j.foodchem.2013.04.044.

Kumar V, Modi PK, Sharma S. 2012. Evaluation of anti-inflammatory activity of Tinosporacordifolia: role in arthritis. Int J Pharm Res BioSci 1 (5): 193-204.

Kuo CL, Chia CW, Liu TY. 2004. The anti-inflammatory potential of berberine in vitro and in vivo. Cancer Lett 203: 127-137. DOI: 10.1016/j.canlet.2003.09.002.

Küpeli E, Koşar M, Yeşilada E, Başer KHC. 2002. A comparative study on the anti- inflammatory, antinociceptive and antipyretic effects of isoquinoline alkaloids from the roots of Turkish Berberis species. Life Sci 72 (6): 645-657. DOI: 10.1016/S0024-3205(02)02200-2.

Liu RH. 2003. Health benefits of fruit and vegetables are from additive and synergistic combinations of phytochemicals. Am J Clin Nutr 78 (3): 517S-520S. DOI: 10.1093/ajcn/78.3.517S.

Loizou S, Paraschos S, Mitakou S, Chrousos GP, Lekakis I, Moutsatsou P. 2009. Chios mastic gum extract and isolated phytosterol tirucallol exhibit anti-inflammatory activity in human aortic endothelial cells. Exp Biol Med 234 (5): 553-561. DOI: 10.3181/0811-RM-338.

Lulekal E, Asfaw Z, Kelbessa E, Van Damme P. 2013. Ethnomedicinal study of plants used for human ailments in Ankober District, North Shewa Zone, Amhara region, Ethiopia. J Ethnobiol Ethnomed 9 (1): 1. DOI: 10.1186/1746-4269-9-63.

Masresha B, Makonnen E, Debella A. 2012. In vivo anti-inflammatory activities of Ocimum suave in mice. Ethnopharmacology 142 : 201205. DOI: $10.1016 /$ j.jep.2012.04.041.

Mathew LE, Sindhu G, Helen A. 2014. Dolichos biflorus exhibits antiinflammatory and antioxidant properties in an acute inflammatory model. J Food Drug Anal 22 (4): 455-462. DOI: 10.1016/j.jfda.2014.02.002.

Mehta DS, Kataria BC, Chhaiya SB. 2012. Wound healing and antiinflammatory activity of extract of Ficus racemosa linn. Bark in albino rats. Int $\mathrm{J}$ Basic Clin Pharmacol 1 (2): 111-115. DOI: 10.5455/2319-2003.ijbcp001212.

Mequanint W, Makonnen E, Urga K. 2011. In vivo anti-inflammatory activities of leaf extracts of Ocimum lamiifolium in mice model. Ethnopharmacology 134: 32-36. DOI: 10.1016/j.jep.2010.11.051. 
Miyamoto N, Mandai M, Suzuma I, Suzuma K, Kobayashi K, Honda Y. 1999. Estrogen protects against cellular infiltration by reducing the expressions of E-selectin and IL-6 in endotoxin-induced uveitis. J Immunol 163 (1): 374-379.

Mota ML, Thomas G, Barbosa Filho JM. 1985. Anti-inflammatory actions of tannins isolated from the bark of Anacardium occidentale L. Ethnopharmacology $13 \quad$ (3): 289-300. DOI: $10.1016 / 0378$ 8741(85)90074-1.

Navarro P, Giner RM, Recio MC, M ez S, Cerd -Nicol s M, R os JL. 2001. In vivo anti-inflammatory activity of saponins from Bupleurum rotundifolium. Life Sci 68 (10):1199-1206. DOI: 10.1016/S0024 3205(00)01019-5.

OECD. 2008. Guidelines for the testing of chemicals: Acute oral toxicity up-and-down-procedure (UDP): Guideline 425: [Online] Available at: https://ntp.niehs.nih.gov/iccvam/suppdocs/feddocs/oecd/ oecdtg425.pdf [Accessed 23 February 2015].

Ong CKS, Lirk P, Tan CH, Seymour RA. 2007. An evidence-based update on nonsteroidal anti-inflammatory drugs. Clin Med Res 5 (1): 19-34. DOI: $10.3121 / \mathrm{cmr} .2007 .698$.

Panthong A, Supraditaporn W, Kanjanapothi D, Taesotikul T, Reutrakul V. 2007. Analgesic, anti-inflammatory and venotonic effects of Cissus quadrangularis Linn. J Ethnopharmacol 110 (2): 264-270. DOI: 10.1016/j.jep.2006.09.018.

Pelletier JM, Lajeunesse D, Reboul P, Pelletier JP. 2003. Therapeutic role of dual inhibitors of 5-LOX and COX, selective and non-selective non-steroidal anti-inflammatory drugs. Ann Rheum Dis 62 (6): 501509. DOI: 10.1136/ard.62.6.501.

Peters RR, Saleh TF, Lora M, Patry C, de Brum-Fernandes AJ, Farias MR, Ribeiro-do- Valle RM. 1999. Anti-inflammatory effects of the products from Wilbrandia ebracteata on carrageenan-induced pleurisy in mice. Life Sci 64 (26): 2429-2437. DOI: 10.1016/S00243205(99)00200-3.

Ragunathan M, Abay SM. 2009. Ethnomedicinal survey of folk drugs used in Bahirdar Zuria District, Northwestern Ethiopia. Indian J Tradit Knowledge 8 (2): 281-284

Reddy PP, Rao JV, Sambasiva-Rao KRS. 2015. Pharmacological evaluation of anti- arthritic potential of Momordica cymbalaria. IJPSM 5 (1): 25-31.

Redrejo-Rodriguez M, Tejeda-Cano A, Pinto MDC, Mac as P. 2004 Lipoxygenase inhibition by flavonoids: semi-empirical study of the structure-activity relation. J Mol Struct: THEOCHEM 674 (1): 121124. DOI: $10.1016 /$ j.theochem.2003.12.021

Rhen T, Cidlowski JA. 2005. Antiinflammatory action of glucocorticoids - New mechanisms for old drugs. New England J Med 353 (16): 1711-1723. DOI: 10.1056/NEJMra050541.

Roome T, Razzak A, Ali P, Aziz S, Dar A, Naqvi S, Choudhary MI. 2014. Therapeutic Effect of Aegiceras corniculatum in Chronic Granulomatous Inflammation and Arthritis. J Dow Univ Health Sci 8 (3): 98-103.

Sanusi RAM, Shukor NAA, Sulaiman MR. 2013. Anti-inflammatory Effects of Labisia pumila (Blume) F. Vill-Naves. Aqueous Extract. Sains Malaysiana 42 (10): 1511-1516.

Sarkar M. 2015. Evaluation of the anti-inflammatory activity of methanolic leaf extract of Mangifera indica L. (Anacardiaceae) in rats. Int J Drug Dev Res 7 (3): 21-25.

Sasidharan S, Chen Y, Saravanan D, Sundram KM, Latha LY. 2011. Extraction, isolation and characterization of bioactive compounds from plants' extracts. Afr J Tradit Compl Altern Med 8: 1-10. DOI: 10.4314/ajtcam.v8i1.60483

Schewe T, Kühn H, Sies H. 2002. Flavonoids of cocoa inhibit recombinant human 5- lipoxygenase. J Nutr 132 (7): 1825-1829. DOI: $10.1093 / \mathrm{jn} / 132.7 .1825$

Silva-Neto JAPD, Menezes LD, Gomes GO, Cunha EMF, Azevedo MSD, Ferreira VM, Silva MVD. 2014. Evaluation of antinociceptive and anti-inflammatory activities of the topical preparation of Cipura paludosa (Iridaceae). Acta Amazonica 44 (2): 263-270. DOI: 10.1590/S0044-59672014000200012.

Smit HF, Van den Berg AJJ, Kroes BH, Beukelman CJ, Quarles van Ufford HC, Van Dijk H, Labadie RP. 2000. Inhibition of Tlymphocyte proliferation by cucurbitacins from Picrorhiza scrophulariaeflora. J Nat Prod 63 (9): 1300-1302. DOI: $10.1021 / \mathrm{np} 990215 \mathrm{q}$.
Smyth EM, Grosser T, Wang M, Yu Y, FitzGerald GA. 2009. Prostanoids in health and disease. J Lipid Res 50 (Supp): S423-S428. DOI: 10.1194/jlr.R800094-JLR200.

Souto AL, Tavares JF, da Silva MS, Diniz MDFFM, de Athayde-Filho PF, Barbosa Filho JM. 2011. Anti-inflammatory activity of alkaloids: an update from 2000 to 2010. Molecules 16 (10): 8515-8534. DOI: 10.3390/molecules 16108515 .

Spies CM, Strehl C, Goes MC, Bijlsma JW, Buttgereit F. 2011. Glucocorticoids. Best Pract Res Clin Rheumatol 25 (6): 891-900. DOI: 10.1016/j.berh.2011.11.002.

Stanos S. 2013. Osteoarthritis guidelines: a progressive role for topical NSAIDs. J Am Osteopath Assoc 113 (2): 123-127.

Tadesse WT, Hailu AE, Gurmu AE, Mechesso AF. 2014. Experimental assessment of antidiarrheal and antisecretory activity of $80 \%$ methanolic leaf extract of Zehneria scabra in mice. BMC Complement Altern Med 14 (460): 1. DOI: 10.1186/1472-6882-14460.

Tatke P, Rajan M. 2014. Comparison of conventional and novel extraction techniques for the extraction of scopoletin from Convolvulus Pluricaulis. Indian J Pharm Educ Res 48 (1): 27-31. DOI: 10.5530/ijper.48.1.5.

Teklehaymanot T, Giday M. 2007. Ethnobotanical study of medicinal plants used by people in Zegie Peninsula, Northwestern Ethiopia. J Ethnobiol Ethnomed 3 (1): 1. DOI: 10.1186/1746-4269-3-12.

Tesfaye WH, Alamneh EA. 2014. In vivo antimalarial activity of the crude extract and solvent fractions of the leaves of Zehenria scabra (Cucurbitaceae) against Plasmodium berghei in mice. J Med Plants Res 8 (42): 1230-1236.

Tunon MJ, Garcia-Mediavilla MV, Sanchez-Campos S, Gonzalez-Gallego J. 2009. Potential of flavonoids as anti-inflammatory agents: modulation of pro-inflammatory gene expression and signal transduction pathways. Curr Drug Metab 10 (3): 256-271. DOI: $10.2174 / 138920009787846369$

Umukoro S, Ashorobi RB. 2006. Evaluation of anti-inflammatory and membrane stabilizing property of aqueous leaf extract of Momordica charantia in rats. Afr J Biomed Res 9 (2): 119 -124. DOI: 10.4314/ajbr.v9i2.48892.

Vegeto E, Ciana P, Maggi A. 2002. Estrogen and inflammation: hormone generous action spreads to the brain. Mol Psychiatry 7 (3): 236. DOI: 10.1038/sj.mp.4001007.

Vodovotz Y, Constantine G, Faeder J, Mi Q, Rubin J, Bartels J, Sarkar J, Squires Jr RH, Okonkwo DO, Gerlach J, Zamora R. 2010. Translational systems approaches to the biology of inflammation and healing. Immunopharmacol Immunotoxicol 32 (2) : 181-195. DOI: 10.3109/08923970903369867.

Vodovotz Y, Constantine G, Rubin J, Csete M, Voit EO, An G. 2009. Mechanistic Simulations of Inflammation: Current State \& Future Prospects. Math Biosci 217 (1): 1-10. DOI: 10.1016/j.mbs.2008.07.013

Wagle N, Nagarjuna S, Sharma H, Dangi NB, Sapkota HP, Naik BS, Padhaya RR. 2016. Evaluation of anti-nociceptive and antiinflammatory activity of Phytosterol present in chloroform extract of Phyllanthus maderaspatensis. Ind J Physiol Pharmacol 60 (1):90-95.

Wakimoto N, Yin D, O'Kelly J, Haritunians T, Karlan B, Said J, Xing H, Koeffler HP. 2008. Cucurbitacin B has a potent antiproliferative effect on breast cancer cells in vitro and in vivo. Cancer Sci 99 (9):1793-1797. DOI: 10.1111/j.1349-7006.2008.00899.x.

Weber C, Fraemohs L, Dejana E. 2007. The role of junctional adhesion molecules in vascular inflammation. Nat Rev Immunol 7 (6): 467477. DOI: $10.1038 /$ nri2096

Wendakoon C, Calderon P, Gagnon D. 2012. Evaluation of selected medicinal plants extracted in different ethanol concentrations for antibacterial activity against human pathogens. J Med Active Plants 1 (2): 4

Werz O, Bürkert E, Samuelsson B, Rådmark O, Steinhilber D. 2002. Activation of 5-LOX by cell stress is calcium independent in human polymorphonuclear leukocytes. Blood 99 (3): 1044-1052. DOI: 10.1182/blood.V99.3.1044

WHO. 2002. WHO traditional medicine strategy 2002-2005. WHO, Geneva. 